NBER WORKING PAPER SERIES

\title{
STAPLE PRODUCTS, LINKAGES, AND DEVELOPMENT: EVIDENCE FROM ARGENTINA
}

\author{
Federico Droller \\ Martin Fiszbein \\ Working Paper 25992 \\ http://www.nber.org/papers/w25992 \\ NATIONAL BUREAU OF ECONOMIC RESEARCH \\ 1050 Massachusetts Avenue \\ Cambridge, MA 02138 \\ June 2019, Revised May 2021
}

We thank Samuel Bazzi, William Collins, James Fenske, Eric Hilt, Kevin Lang, Emiliano Libman, Max McDevitt, Dilip Mookherjee, Santiago Perez, Agustina Rayes, Marcelo Rougier, and Gabriella Santangelo as well as seminar participants at University of Ottawa, Universidad de Chile, Boston University, Universidad Nacional de la Plata, the Economic History Clio Lab Meetings at PUC-Chile, the RIDGE Workshop on Macroeconomics and Development, the Economic History Conference at Universidad de San Andrés, the RIDGE Workshop on Economic History, and the LANE HOPE seminar for helpful comments. All errors are our own. Federico Droller acknowledges support from FONDECYT (grant 11170498, Proyecto FONDECYT Iniciacion, CONICYT, Chile). The views expressed herein are those of the authors and do not necessarily reflect the views of the National Bureau of Economic Research.

NBER working papers are circulated for discussion and comment purposes. They have not been peer-reviewed or been subject to the review by the NBER Board of Directors that accompanies official NBER publications.

(C) 2019 by Federico Droller and Martin Fiszbein. All rights reserved. Short sections of text, not to exceed two paragraphs, may be quoted without explicit permission provided that full credit, including $\odot$ notice, is given to the source. 
Staple Products, Linkages, and Development: Evidence from Argentina

Federico Droller and Martin Fiszbein

NBER Working Paper No. 25992

June 2019, Revised May 2021

JEL No. N16,N56,N96,O13,O14

\title{
ABSTRACT
}

We investigate how historical patterns of primary production influenced development across local economies in Argentina. Our identification strategy exploits exogenous variation in the composition of primary production induced by climatic features. We find that locations specializing in ranching had weaker linkages with other activities, higher concentration in land ownership, lower population density, and less immigration than cereal-producing areas. Over time, ranching localities continued to exhibit lower population density and they experienced relatively sluggish industrialization. Ultimately, ranching specialization had large negative effects on long-run levels of income per capita and human capital.

\author{
Federico Droller \\ Department of Economics \\ Universidad de Santiago de Chilé \\ Av. Lib. B. O'Higgins 3363 \\ Estacion Central, Santiago \\ Chile \\ federico.droller@usach.cl \\ Martin Fiszbein \\ Department of Economics \\ Boston University \\ 270 Bay State Road \\ Boston, MA 02215 \\ and NBER \\ fiszbein@bu.edu
}




\section{Introduction}

Different goods have different production functions. The types of goods produced by an economy are bound to influence its development path. This influence is more apparent in economies with a prominent, undiversified primary export sector, as highlighted by the staple theory of growth (Innis, 1930, 1940). The production function of export staples determines factor demands and the distribution of income. In addition, the backward and forward linkages of staples determine investment opportunities in other activities. Thus, the features of staple products can shape the whole economy and have a marked influence on the process of growth and structural change.

This paper examines how primary production patterns shaped development across local economies in Argentina. In the late 19th and early 20th century, Argentina underwent a rapid process of integration into the international economy as an exporter of primary goods. The leading staples were ranching products and cereals, which had contrasting features along multiple dimensions. Ranching was characterized by an extensive production system, whereas cereals were labor-intensive and usually more intensive in the use of inputs and capital. Cereals' main forward linkage, flour mills, often located close to their input sources, while ranching's main forward linkage, meat-processing industries, were concentrated around the Buenos Aires port.

Taken together ranching products and cereals represented the greater part the country's exports and employed most of the land in the Pampas, Argentina's core agricultural region. At the same time, there was considerable variation across local economies in the prevalence of each staple, partly due to variation in climatic features. This is an interesting context to examine the effects of primary products on the process of development.

Our identification strategy exploits the climate-induced variation in agricutural production mix. In particular, we construct an instrumental variable based on high resolution spatial data on climate-based potential yields for pastures, wheat, corn, and flaxseed. The IV is based on the estimation of a fractional multinomial logit (FML) model of crop choice in which the countylevel shares of primary products in total agricultural land use are functions of the productspecific potential yields. In particular, the predicted share of ranching in local agricultural land ("potential ranching specialization") can be used as an IV for actual ranching specialization.

We find that localities specializing in ranching historically had weaker linkages with other activities, higher land concentration, lower population density, and less immigration of Euro- 
peans. In terms of linkages, ranching areas had less investment in agricultural machinery, lower railroad density, and weaker development of agro-processing industries. Moreover, ranching's extensive production system was conducive to land concentration, presumably increasing income inequality. In addition, ranching's low labor-intensity led to low populations densities. Thus, ranching areas were likely to have thin local markets and limited agglomeration effects. Finally, ranching localities had low shares of European immigrants, whose skills were more complementary to cereal production. In turn, the European presence in cereal producing areas created an advantage for industrial and commercial activities.

After studying how ranching specialization shaped local economies historically, we move on to show how it hampered subsequent development. The importance of ranching was lessened as the national economy industrialized and diversified, but the influence of early ranching specialization across local economies did not wash out over time. The negative effects on population density and urbanization were remarkably persistent. Moreover, ranching locations displayed slower industrialization, with lower skill-intensity in manufacturing activity. Ultimately, ranching had negative long-run effects on income per capita and education. According to our estimates a reduction of one standard deviation in ranching specialization would increase long-run levels of population density and income per capita by 0.35 and 0.52 standard deviations, respectively.

Our results suggest that the composition of agricultural production shaped the process of development in multiple ways. We highlight the likely feedbacks among the various channels mentioned above, without attempting to assess their relative importance in accounting for the long-term effects of ranching specialization. We discuss some potential forces that cannot be captured in our subnational analysis but may be relevant from an aggregate perspective, possibly affecting the overall effects of ranching on development.

We examine three other mechanisms through which ranching may have affected development. First, ranching could have been associated with differential productivity growth or export prices in the primary sector, which may have affected the reallocation of labor to the industrial sector. Second, ranching differed from cereal production in terms of seasonality patterns, which may have had implications for the process of structural change. Third, the association of ranching with land concentration suggests possible negative effects on education through political economy mechanisms. Based on an assessment of available evidence, these channels do not 
seem relevant in our context.

Our regressions control for state fixed effects, land productivity measures, and other geoclimatic features that might be correlated with ranching specialization and have direct effects on development, such as precipitation, temperature, elevation, terrain ruggedness, and distance to Buenos Aires City. Given that our IV is based on measures of productivity for specific crops, it is important to control for overall agricultural productivity to mitigate potential concerns about the exclusion restriction. In our robustness checks, we show that flexibly controlling for multiple measures of land productivity in a variety of specifications does not affect the results. Our findings are also robust to accounting for spatial dependence using Conley standard errors with various distance cutoffs.

This paper contributes to a large literature on the role of agriculture in economic development (e.g., Johnston and Mellor, 1961; Gollin, 2010). In particular, we add to a strand of this literature that studies the effects of specialization in particular products as a result of their distinctive features, e.g., returns to scale, seasonality or labor intensity (Engerman and Sokoloff, 1997; Sokoloff and Dollar, 1997; Eberhardt and Vollrath, 2016). We rekindle the staple theory of economic growth (Innis, 1930, 1940) and the theory of linkages (Hirschman, 1958), examining various ways in which primary products can shape the process of growth and structural change. We exploit rich subnational variation and propose a modern empirical strategy aimed at identifying the causal effects of primary products on development, like the recent contributions of Bustos et al. (2016) and Dell and Olken (2020). We are the first to do this with data from Argentina, leveraging the presence of two salient staples with contrasting features within the same macro-institutional context.

We also contribute to Argentina's economic historiography. A prominent theme in the literature is the "Argentine puzzle" (Della Paolera and Gallo, 2003; Taylor, 2018)—the contrast between the glowing prospects of the early 20th century and the weak, erratic economic performance over the long-run. Our research links the growth trajectories of local economies after the period of rapid growth led by primary exports with economic features from that booming period. Ranching specialization, limited diversification into related activities, land concentration, and low population density, which hampered development at the subnational level, were salient characteristics of the Argentine economy as a whole. Our findings may thus be suggestive for country-level narratives, though direct extrapolation from subnational analysis would 
only be speculative. After presenting our results on the effects of ranching on long-run development, we discuss reasons why the effects of ranching at the national level may have been different than in our subnational analysis.

A broad implication of our results is that models with finer levels of aggregation than standard two- or three-sector macro-development models may be needed to understand the process of growth and structural change. This is in line with a number of recent contributions that stress the relevance of input-output connections (e.g. Jones, 2011; Bartelme and Gorodnichenko, 2015) as well as other types of linkages, e.g. those based on similarities in labor skills and technologies (Hausmann and Hidalgo, 2011; Ellison et al., 2010; Hanlon and Miscio, 2017; Cai and Li, 2019). Focusing on the relatively simple context of highly specialized agricultural economies, we provide clear-cut evidence that the composition of production can influence the growth process through various sorts of linkages. Moreover, our paper suggests that is important to study the role of linkages in the growth process over the long run.

The paper is organized as follows. Section 2 reviews the literature on the agricultural roots of comparative development with an emphasis on the different channels through which specialization in specific agricultural products may affect paths of long run development. Section 3 describes some broad facts of Argentine economic history providing context for our study and presents the data sources that we use. Section 4 introduces the estimating equations and explains our instrumental variable strategy. Section 5 examines our estimates of the effects of ranching specialization on historical outcomes, and Section 6 examines the effects on the process of development over time. Section 7 studies other possible mechanisms not covered in our main analysis. Section 8 concludes.

\section{Conceptual Framework}

To analyze how primary production patterns at early stages of development influence the evolution of the economy, we draw from the staple theory of growth and from the concept of linkages. The staple thesis was advanced by the studies of Innis $(1930,1940)$ on the Canadian fur trade and cod fisheries, and it was further elaborated by Baldwin (1956), Watkins (1963), and several others. The focus was on "regions of recent settlement" (a term adopted by the League of Nations, 1942, and Nurkse, 1954), such as Canada, Argentina, Australia, New Zealand, South Africa, the United States, and Uruguay, which underwent rapid integration into world markets 
during the "first globalization" (1870-1914). These economies had an abundance of land relative to labor and capital, which created a comparative advantage in primary exports. The export sector thus became the leading engine of growth, leaving a mark on the whole economy.

The proponents of the theory argued that in staple-export economies development is the process of diversification around the staple, and that this process is shaped by the characteristics of the staple's production. The production function of the staple determines the demands for factors and intermediate inputs, the distribution of income, and investment opportunities in related activities. For instance, a key feature of the production function emphasized in the literature is the degree of returns to scale: crops with increasing returns to scale have been associated with slave plantations, inequality in the distribution of income, and low levels of diversification.

The ways in which the staple's features shape development can be organized around the notions of backward linkages, forward linkages, and demand linkages advanced by Hirschman (1958) (see also Hirschman, 1977). Backward linkages are determined by the production function of the staple and the domestic potential to produce the required inputs. While intermediate inputs and capital goods used in the staple's production are often imported, in some cases the staple requires an array of goods that can be domestically supplied. This fosters local production capabilities. One requirement of staple exports is the creation of transport systems. These in turn have positive economy-wide effects.

Forward linkages are investment opportunities induced by staples in activities that use them as inputs; the features of a staple and the related processing industries determine the scope for vertical integration. Demand linkages are investment opportunities induced by staples in consumer goods industries; these are determined by the overall income created by staple production as well as income distribution patterns induced by each staple's production function.

A number of contributions have examined the influence of specific agricultural products on industrialization through channels other than backward, forward, and demand linkages. Goldin and Sokoloff (1984) point out that specialization in hay, wheat, and dairy provided a low-cost labor supply for manufacturing because the relative productivity of women and children in these crops was much lower than in plantation crops. Earle and Hoffman (1980) link the availability of cheap labor for manufacturing to the production of wheat, corn, and livestock due to their highly seasonal labor requirements. Sokoloff and Dollar (1997) also emphasize 
the seasonality of grains, but they argue that seasonal availability of cheap labor could hinder the adoption of more efficient manufacturing technologies. Vollrath (2011) and Eberhardt and Vollrath (2016) study how the elasticity of agricultural output with respect to labor affects the process of structural change.

Other work has shown that agricultural production patterns can influence institutions and culture. In their influential work on compartive development in the Americas, Engerman and Sokoloff (1997) and Engerman and Sokoloff (2002) argue that scale economies in the production of cotton, sugar, rice, tobacco, and coffee induced slave plantations and generated inequalities that became embodied in institutions, ultimately harming long-run performance (see also Nunn, 2008; Bruhn and Gallego, 2012). In a recent study with Chinese data, Talhelm et al. (2014) argue that rice production fosters collectivistic cultures, whereas wheat production is more conducive to individualism.

While the classic formulation of the staple theory focuses on backward, forward, and demand linkages, all the contributions mentioned above could fit into the "generalized linkage approach" proposed by Hirschman (1977). This version of the theory encompasses all possible connections between staple production and subsequent development. As Hirschman put it, "development is essentially the record of how one thing leads to another, and the linkages are that record."

We study the multiple ways in which staples shaped the development process across local economies in the Argentine pampas. We find that localities specializing in ranching historically had weaker linkages with other activities, higher land concentration, and lower population density. These distinctive features of ranching were noted by Geller (1970) in his analysis of the Argentine economy; Dyster (1979), citing a study of Uruguay by Winn (1976), wrote that "a pastoral economy generates of itself very few linkages for the region in which the grasslands are located," because "[o]nce the crude extraction of the primary commodity has taken place, all that is needed in the country of origin is a set of rails or a caravan of drays, a long wharf and some sturdy fellows to load and unload." We provide evidence on the channels mentioned above as well as on the link between ranching and European immigration. We also study how ranching shaped the process of development over the long run.

The classic staples approach was widely applied in development research, featuring in studies of Canada (Caves and Holton, 1959; Caves, 1971), Australia (McCarty, 1964, 1973), the US 
(North, 1955, 1966; Williamson, 1980), and Argentina (Geller, 1970; Gallo, n.d.; Diaz Alejandro, 1970), as well as in cross-country comparative studies (e.g., Schedvin, 1990; Altman, 2003). However, the theory was criticized for overemphasizing the importance of the export sector, and ultimately its influence diminished. Most research in this tradition consisted of case studies focusing on one or a few economies, making their findings wide-open to confounding factors. Such concerns are mitigated in our analysis, which uses data from 150 local economies and exploits climate-induced variation in primary production patterns.

\section{Historical Background and Data}

In the late 19th century and early 20th century, Argentina went through a rapid process of integration into the international economy as an exporter of primary goods. Between 1880 and 1913 exports grew at average annual rates of 7.5\%, led by cattle products and cereals. During the same period, income per capita grew at an average annual rate of $3.4 \%$, with annual population growth averaging 3.4\%. Population growth partly reflected a massive arrival of international migrants, mostly from Europe. Between 1880 and 1913 the population grew from about 2.5 million to 7.5 million, with a cumulative net inflow of migrants in this period above 2.8 million (Ferreres et al., 2005).

The take-off of export-led growth was based not only on the famed fertility of Argentine plains coupled with labor force expansion through immigration, but also on the sweeping extension of railroads (Campi, 2012). The first railway was inaugurated in 1857, with a route of $10 \mathrm{~km}$ within the Buenos Aires City; by 1914 the tracks stretched over 34,500 km. In 1880 railroads transported less than one million tons of cargo; in 1914 they hauled over 40 million tons. Passenger travel grew from 2.75 millions in 1880 to 82.3 millions in 1913 (Tornquist, 1919). Connecting the Pampas to the port of Buenos Aires City greatly expanded the scope for profitable production of agricultural goods oriented to world markets. More broadly, the reductions in transport costs and increased flows of commodities and labor facilitated by railroads were key sources of growth in this period (Fajgelbaum and Redding, 2014; Perez, 2018).

Our sample covers the provinces of Buenos Aires, Córdoba, Entre Ríos, and Santa Fe, the core of the so-called Pampas, the fertile plains stretching westward from the Atlantic coast (see Figure A1). The starting point of our analysis is the year 1914, commonly identified as the closing of the agricultural frontier and the height of the agricultural export-led growth period 
(Di Tella and Zymelman, 1973). We consider counties (departmentos or partidos) as defined in 1914; for counties that experienced changes in boundaries after 1914 we consider the post 1914 data of the county that corresponds most closely to the 1914 county. ${ }^{6}$

Argentine exports were heavily concentrated. In 1913, ranching products represented over $35 \%$ of exports; almost two thirds of these were cattle products (chilled and frozen meat, live cattle, jerked beef, cattle hides) and the rest were sheep products (wool, meat, and hides). Cereals (wheat, corn, and oats) amounted to about $45 \%$ of exports. Flax represented 9.6\%. The remainder comprised quebracho tree products $(2.5 \%)$, wheat flour $(1.4 \%)$, and other products (6.6\%) (Rayes, 2015). In stylized terms, as discussed in detail later in this section, we view the agricultural production of the Pampas in this period as comprising two main staples: ranching products and cereals.

Exports of frozen meat surged starting in the late 19th century, prompted by the advent of refrigerated ships. Technical innovations enabled a rapid expansion in cattle production (Hora, 2001; Sesto, 2005; Campi, 2012). Ranchers made large investments to introduce imported breeds, mostly from the UK, adapting local production to international demand. Between 1895 and 1914 pure breeds increased from $0.6 \%$ to $2.5 \%$ of all cattle, and mestizos, the crossbreed between pure breed and local cattle, increased from $49 \%$ to $94 \%$ (Comision Nacional del Censo, 1916-1919). ${ }^{7}$ Accompanying the advances in livestock management, there was a broad modernization of ranches, including the introduction of pasture grasses and better infrastructure such as fencing and sheds.

Despite increased investments, ranching continued to display an extensive production system, using low levels of labor and capital relative to land. By contrast, cereals were intensive in labor, tools (e.g., plows), and inputs (e.g., fertilizer). As cereal production took off in the late 19th century and early 20th century, propelled by the expansion of railroads and the inflow of migrants, technology improved and capital-intensity increased, with the incorporation of threshing machines as a key milestone (see, e.g. Bil, 2009a).

We use detailed data on the county-level composition of primary production from the 1914 National Census compiled from the original books published by Comision Nacional del Censo

\footnotetext{
${ }^{6}$ Our results are qualitatively the same if we make adjustments in the post 1914 data based on spatial interporlation or if we exclude from our sample the small number of counties that experienced major boundary changes after 1914.

${ }^{7}$ For sheeps there was a similar pattern of breed improvement, but at the same time there was a movement toward less productive farmland.
} 
(1916-1919). Appendix Table 1 shows summary statistics for the shares of land corresponding to each of the seven main uses in the Argentine Pampas in 1914. The share of farmland used for ranching in the first column of this table is our measure of ranching specialization in the analysis presented in the following sections. The eighth category, "others," combines 15 agricultural products, each one representing less than $0.5 \%$ of total agricultural land use. Ranching was by far the dominant use of agricultural land, with a share much larger than the share of ranching products in exports or output, partly reflecting its extensive nature.

We view the agricultural production of the Pampas as comprising two main staplesranching products and cereals. We abstract from differences in the production of cattle and sheep. The production processes involved were relatively similar. Moreover, while sheep products still had a large presence in Argentine exports by 1914, in the Pampas cattle was already markedly dominant, as sheep had been largely reallocated to less productive farmland outside this region. ${ }^{8}$ We also abstract from differences between wheat, corn, and oats, and consider flax as another cereal, given the similarities in production. ${ }^{9}$ All other primary products of the Pampas were marginal or for home consumption.

Figure 1 displays the spatial distribution of ranching specialization, measured by share of farmland used for ranching, across counties in the Pampas in 1914. All four provinces in our sample displayed significant variation in the importance of ranching across counties. In each province, there were counties with more than $80 \%$ of land allocated to ranching as well as counties where other products accounted for more than 50\% of agricultural land. There were barely any cases of full specialization in our sample; mixed production of ranching products and cereals was common at the local economy level and even at the micro level. ${ }^{10}$ But for convenience, we often refer to the right and left tails of the distribution of ranching specialization across counties with the terms "ranching areas" and "cereal producing areas."

To trace the effects of ranching specialization on development, we use historical data on

\footnotetext{
${ }^{8}$ From 1888 to 1914, while the stock of cattle in the Pampas remained stable, the stock of sheep went down by over $50 \%$ in that region and expanded greatly in the rest of the country (Comision Nacional del Censo, 1916-1919, Tomo 6, pp. 31-35).

${ }^{9}$ The 1908 Census of Agriculture makes the point that flax's stages of production-terrain preparation, sowing, cultivation, harvest, threshing-were all similar to the analogous ones for wheat (Comision Nacional del Censo, 1909, Tomo 3, p. 410).

${ }^{10}$ In the late 19th and early 20th century, it was increasingly common for large landowners to rent fractions of their properties to cereal farmers. Beyond responding to profit opportunities created by rising exports of cereals, landowners used farmers to transform wild grasslands into higher-quality grazing places (Conde, 1966; Slutzky, 1968; Palacio, 2002). The typical "arrendamiento" contracts that became widely extended were for two or three years and stipulated that farmers would sow the land with alfalfa in the last period.
} 
population, farm sizes, farm capital, railroads, immigration, industrial production, employment, and occupational structure from the 1914, 1947 and 1970 National Census of Population and the 1947 Census of Manufactures. To capture long-run economic development we use proxies of income per capita and non-agricultural income per capita in 1994, and two measures of human capital, years of schooling and primary school completion in 2001. Figure A2 shows the spatial distribution of some key long-run outcomes: non-agricultural income per capita (in logs) in 1994, the urban share in 2001, and average years of schooling in 2001. The Appendix contains detailed descriptions of all variables and data sources. Appendix Table A1 provides summary statistics.

\section{Empirical Strategy}

\subsection{Estimating Equation}

Our estimating equations takes the the following form:

$$
y_{c}=\alpha+\beta \text { Ranching }_{c, 1914}+\delta_{p}+\gamma^{\prime} \mathbf{X}_{c}+\varepsilon_{c}
$$

where $y_{c}$ is a development outcome for county $c$, Ranching ${ }_{c, 1914}$ is ranching specialization in $1914, \delta_{p}$ is a state (provincia) fixed effect, $\mathbf{X}_{c}$ is a vector of control variables, and $\varepsilon_{c}$ is an error term.

Throughout the paper we consider multiple outcome variables. We start by considering a number of outcomes in 1914, at the height of the agro-export period, capturing how staples shaped local economies historically. We then consider population density, industrialization, and other outcomes at various points in time to establish the effects of ranching specialization on the development process. For each outcome we consider a variety of specifications, sequentially expanding the set of controls to include provincia fixed effects, land productivity and other geoclimatic controls, and distance to Buenos Aires city.

As land productivity measures we use the mean and the first principal component of the climate-based measures of attainable yields (in tons per hectare per year) for pasture grasses, wheat, corn, and flax from the Global Agro-Ecological Zones (GAEZ) project version 3.0 (IIASA/FAO, 2012). ${ }^{11}$ Controlling for land productivity is crucial to avoid confounding the

\footnotetext{
${ }^{11}$ To make the yields of different crops comparable before taking the mean, we normalize each measure by the
} 
effects of ranching specialization with the effects of agricultural resource abundance. It is also important to control for geo-climatic variables that may be correlated with ranching specialization and also have an independent effect on development outcomes. Thus, we include mean annual precipitation, annual temperature, terrain elevation, and ruggedness. Finally, we control for the distance (in logs) to the city of Buenos Aires, the capital city and main port of the country, which could be correlated with ranching specialization and also affect market access for local production as well as the inflow of new ideas.

\subsection{Instrumental Variables Strategy}

OLS estimates of equation (1) may not reflect a causal relationship. The correlations observed between ranching and some contemporaneous outcomes might reflect reverse causality. For instance, while land concentration can be a consequence of ranching specialization, the former could also be a determinant of the latter. Moreover, all the correlations of early ranching specialization with contemporaneous historical outcomes and with long-run outcomes might be driven by omitted variables. For instance, ranching specialization-which was prevalent during colonial times-might reflect limited openness to new ideas, which would also hinder development. To address these concerns, we introduce an instrumental variable (IV) strategy.

Aiming to isolate exogenous variation in the composition of agricultural production, we construct an IV using attainable yields for different crops from FAO-GAEZ. These measures of potential productivity are computed at a high spatial resolution on the basis of climatic data and crop-specific characteristics. They are based on controlled experiments and expert knowledge of climatic features affecting agricultural production processes; they do not rely on statistical analysis of production patterns observed across the world. The climatic data and crop-specific characteristics are unaffected by the decisions of individuals farmers or the crop mix of any given locality. The climatic data comes from records for 1961-1990, which provide reasonably good proxies for historical conditions (see Nunn and Qian, 2011, for a discussion).

Figure 2 displays the attainable yields for pasture grass, corn, wheat, and flax across counties in the Pampas. For simplicity we consider county-level means. In all cases we use attainable yields for rain-fed conditions and intermediate inputs/technology as defined by IIASA/FAO (2012), since these correspond most closely to the historical context under consideration.

maximum attained in the sample. 
To construct an instrumental variable based on crop-specific attainable yields from FAOGAEZ, we use a fractional multinomial logit (FML) framework (see Ramalho et al., 2011; Mullahy, 2015). In the context under consideration the FML model is specified as a system of equations in which the outcome variables are the shares of each agricultural product $i$ in total agricultural land in county $c$ and the regressors are the crop-specific potential yields $\mathbf{A}_{c}$. For simplicity we focus on ranching, corn, wheat, and flax, with a residual share (which is below $5 \%$ on average) aggregating all other products. Thus, our vector of potential yields includes crop-specific potential yields for pasture grasses (ranching), wheat, corn, and flax.

The functional form of the FML model is

$$
\hat{\theta}_{i c}=E\left[\theta_{i c} \mid \mathbf{A}_{c}\right]=\frac{e^{\phi_{i}^{\prime} \mathbf{A}_{c}}}{1+\sum_{j=1}^{I-1} e^{\phi_{j}^{\prime} \mathbf{A}_{c}}}
$$

By construction, $\sum_{i=1}^{I} \hat{\theta}_{i c}=1$, i.e. the predicted shares for each county add up to 1 . The parameters are estimated by quasi-maximum-likelihood.

The FML model captures how productivity for a specific product relative to other ones influences product choice. Intuitively, for a given location, higher potential yield for pasture grasses, relative to other crop-specific yields, is likely to lead to higher specialization in ranching. The presence of multiple alternatives to ranching in the model's structure makes it more flexible and powerful in capturing how variation in potential yields for various crops, across locations, influence product choice, including ranching specialization.

The system of equations for product shares in land use specified by (2) is the basis of the "zeroth stage" in our estimation procedure. With the estimated coefficients of the FML model, in combination with the product-specific potential yields, we get the share of ranching in land use for each county predicted by the FML model. This "ranching potential share" is then used as IV for the actual share of ranching. Figure 3 displays a scatter plot of county-level actual and potential ranching shares in total farmland use.

We proceed with two-stage-least-squares (2SLS) estimations in which equation (1) described above is the second stage, and the first stage is given by

$$
\text { Ranching }_{c, 1914}=\zeta+\rho \text { Ranching } \text { Potential }_{c, 1914}+\psi_{p}+\lambda^{\prime} \mathbf{X}_{c}+\nu_{c}
$$

where Ranching ${ }_{c, 1914}$ is ranching specialization in 1914 for county $c$, Ranching Potential ${ }_{c, 1914}$ is 
the IV, the ranching potential share generated by the FML model, $\psi_{p}$ is a state (provincia) fixed effect, $\mathbf{X}_{c}$ is the same vector of control variables included in equation (1), and $\nu_{c}$ is an error term.

The identifying assumption is that the potential ranching share, predicted by the FML model, only affects development outcomes through actual ranching specialization. For instance, if areas with low suitability for all crops were particularly bad for cereals and not so bad for pasture grasses, our IV would be (negatively) correlated with overall productivity, violating the exclusion restriction. For the empirical strategy to be valid, we need to appropriately control for overall primary productivity in the 2SLS estimation. In our baseline analysis we control for the mean and the first principal component of the climate-based product-specific productivity measures used for the IV construction in the zeroth stage. Later in the paper we show that the results are robust to controlling flexibly for these and other land productivity measures.

To alleviate other possible concerns, recall that the FAO measures of potential yields for different crops do not rely on a statistical analysis of observed production patterns. Moreover, note that insofar as determinants of crop choice other than the climate-based productivity measures have their effects loaded onto the residuals of the FML model, they do not affect the IV estimates of the effects of ranching specialization.

A sufficient condition for standard errors to be correct when using a generated instrumental variable (here, ranching potential share) requires the expectation of the error term in the estimating equation, conditional on the variables used in the IV construction (here, the crop-specific potential yields), to be zero (see Wooldridge, 2010). This sufficient condition is satisfied insofar as the estimating equation adequately controls for measures of overall land productivity and climatic variables that may have direct effects on development outcomes. As mentioned before, our baseline analysis includes controls for mean annual precipitation, annual temperature, terrain elevation, ruggedness, and two measures of land productivity. We include additional controls for land productivity in our robustness checks.

\section{The Distinctive Features of Ranching Economies}

This section shows how ranching specialization shaped local economies during the period of growth led by primary exports. We show that ranching had relatively weak linkages with other activities. Moreover, its extensive production mode was conducive to large farm sizes and low labor intensity. Finally, ranching areas attracted less European migrants, which had important 
implications for the local composition of skills.

\subsection{Backward and Forward Linkages}

The backward linkages of ranching were weaker than those of cereal production. Besides land, the main investment in cattle production was cattle itself. According to estimates from 1914 Census, the value of livestock accounted for about 75\% of the capital (excluding land) in ranching activity. Ranchers invested heavily in animals, but relatively little in infrastructure. As discussed before, innovations to improve the quality of cattle, particularly through the introduction of high-quality imported breeds, were key drivers of the rise of cattle exports.

By comparison, cereal production required significant investments in inputs and capital, e.g. fertilizer, tools, and machinery. The expansion of cereal production in Argentina led to the development of small foundries. Santa Fe, the province with the highest cereal shares among the four ones in our sample, had over 2,500 foundries in 1895 (Martino and Delgado, 1977). These produced plows and various other agricultural tools, mills, wire, threshing machine belts, and other replacement parts. Foundries later developed in Córdoba and Buenos Aires, following local demand spurred by the growth of cereal production. While the domestic agricultural machinery industry never supplied more than a small fraction of domestic demand, it displayed considerable dynamism over the 20th century, entering the production of threshing machines in the 1910s and mass production of tractors in the 1950s (Bil, 2009a,b).

Another difference in backward linkages concerned the demand for transportation services. Cattle production had a relatively low demand for railroad services, because cattle could be moved to the Buenos Aires port on foot (Cortés Conde, 1968). In contrast, profitably carrying cereals to Buenos Aires usually required access to railroads. Some regions of Santa Fe and Entre Ríos used rivers as a mean of transportation, in particular the Paraná river. But the use of waterways as means of transportation was limited. The transportation of cereals also created a demand for grain elevators, although their diffusion in Argentina was slower and more limited than in the U.S. and Canada (Scobie, 1964).

In Table 2 we examine the effects of ranching specialization on capital intensity in farms and railroad density. We present results for three specifications, sequentially expanding the set of controls to include province fixed effects, land productivity measures, and other geo-climatic controls. Panel A displays OLS estimates. Panel B displays IV estimates obtained using the 
ranching potential share from the FML model as an IV for actual ranching specialization in 1914. Table 3 shows the first stage results and the Kleibergen-Paap F-statistics. The IV has strong predictive power in all specifications.

The estimates indicate that ranching was characterized by significantly weaker backward linkages. The results are robust across all specifications, with the IV estimates somewhat larger in magntiude than the OLS estimates. Throughout the paper, the OLS and IV estimates have in most cases comparable magnitudes, showing no systematic pattern of bias in OLS estimates. Appendix Table A3 shows that the association between ranching and railroads is robust to controlling for distance to the Paraná river, an alternative means of transportation.

We now turn to forward linkages. The main downstream connections of cattle and cereal production-meat-processing and milling, respectively-were among Argentina's main industrial activities at the turn of the century. Both of them were technologically dynamic. However, their locational patterns and the implications for counties supplying their inputs were dissimilar.

Meat-processing was concentrated near the Buenos Aires port in a small number of large plants. Traditional slaughterhouses (mataderos and saladeros) were swiftly replaced by modern meat-packing plants (frigorificos) following the introduction of refrigeration technologies in the late 19th century (see, e.g., Gebhardt, 2000). The British and American firms dominating this activity located near the port to facilite transportation to international markets and gain access to large labor pools. These firms had advanced know-how, sophisticated marketing methods, and well-developed distribution networks. But there was little spillover to other activities and no externalities on the local economies that supplied the primary goods. ${ }^{12}$

In contrast, flour mills were geographically scattered, often located close to their primary input sources. In 1907 there were 71 flour mills located in the province of Buenos Aires, 43 in Santa Fe, 36 Entre Rios, and 22 in Cordoba, and 178 elsewhere in the country. A large share of mills were steam-powered and used state-of-the-art technologies. ${ }^{13}$ Flour exports were small in comparison to exports of cattle products, but they also experienced rapid growth. In 1913 they represented $1.4 \%$ of total Argentina exports (Rayes, 2015). Most of the wheat flour production was used locally by bakeries and other food processing industries. The technologies and capital

\footnotetext{
${ }^{12}$ Ranching activities also had other forward linkages, including dairy industries, tallow production, and wool washing (see Regalsky and Jáuregui, 2012; Kuntz-Ficker and Rayes, 2017), but their importance remained limited.

${ }^{13}$ See the report on La Industria Harinera by Emilio Lahitte included in Comision Nacional del Censo (1909), Tomo III, and Lluch and Rayes (2013).
} 
goods used in these activities were in most cases not very advanced, but they were locally supplied and generated various spillovers in local economies. ${ }^{14}$

In sum, existing historical research suggests that the forward linkages of ranching were much weaker than those of cereal production, at least at the local level. While we do not assess whether the local presence of different primary products favored the development of related agro-industrial activities, later in the paper we assess how early ranching specialization influenced the process of industrialization more broadly.

\subsection{Land Concentration and Labor Intensity}

Cattle ranching also had differential patterns of factor demand. The extensive nature of cattle ranching led to larger land holdings. Considering the four provinces in our study, the average plot size for farms with crop cultivation as their main use was 133 hectares, while the average size for those with cattle ranching as their main use was 790 hectares (Comision Nacional del Censo, 1916-1919, Tomo V, p. 691 and Tomo VI, p. 523).

The extensive nature of ranching was also associated with low labor intensity, and thus with lower population densities and lower urbanization rates. According to Ortiz (1978), in the late 19th century a herd of 5,000 cattle would occupy about 9 square miles and require 3 laborers, while crop cultivation in a similar extension of land would employ about 350 people. Labor requirements remained low after the modernization of ranches. Improved livestock management required additional workers, but on the other hand fencing reduced surveillance needs (Gebhardt, 2000).

In Table 4 we show that ranching specialization was positively associated with land concentration (columns 1-3). Moreover, it was negatively associated with population density (columns 4-6), and urbanization (columns 7-9), though for the latter the IV estimates are not statistically significant. These results imply that local markets in ranching areas were significantly thinner.

Land concentration and population sparsity in ranching areas implied weak demand linkages. The distribution of income in ranching locations was very unequal. Workers had rudimentary living conditions. Their diet was almost exclusively meat and they had primitive housing. With low labor intensity in production, overall labor shares in income were low, and land shares high. Resource rents were appropriated by a relative small number of landowners, and did not

\footnotetext{
${ }^{14}$ For an overview of the Argentine flour industry during the agro-export model, see Kornblihtt (2013) and Martiren and Rayes (2016).
} 
translate into significant demand at the local level. Landowners spent a high share of their incomes in luxury consumption goods produced abroad, and their investments were mostly on improving cattle, with little demand for local suppliers. ${ }^{15}$

Population sparsity in ranching areas implied isolation and contributed to making local markets thin, probably limiting local commerce to a few general purpose stores scattered in the rural landscape. As an illustration, picture the complete absence of urban agglomerations in the 17 counties in our sample that had urban rates of $0 \%$, all of which had ranching shares above 0.90 (in most cases above 0.95 ). Low population density was also bound to stifle agglomeration effects and scale economies in production.

In cereal producing areas the demand from the local population induced the expansion of small shops and artisans. Manufacturing production during the Argentine agro-export model was limited, but small towns often developed a local supply of bread, pastries, beverages, and other food items, as well as garments, candles, soap, bricks, tiles, furniture, and other household goods (Rocchi, 2005). By contrast, in ranching areas there was little incentive to enter production of consumer goods or tools.

The weak demand linkages of ranching economies, their low levels of investment, and muted agglomeration effects due to low density were bound to induce a weak process of growth. We discuss this further later in the paper.

\subsection{Immigration and Skills}

Argentina was a leading destination in the age of mass migration. For the region we consider in this study, over 25\% of the total population in 1914 had been born in Europe. Close to half of these European immigrants were Italian and around a third were Spanish.

Ranching offered limited opportunities for migrants due to low labor requirements, whereas cereal-producing areas exerted a stronger pull on immigration. Limited access to land implied that migrants could, at best, exploit relatively small plots of land, which were better suited for cereal production. Moreover, as argued by Gerchunoff and Torre (2014), comparative advantage pointed Argentines toward ranching and Europeans toward crop cultivation. Horseback riding,

\footnotetext{
${ }^{15}$ See the report on La Estancia Argentina by Godofredo Daireaux, included in the 1914 Census (Comision Nacional del Censo, 1916-1919, , Tomo III), Rodríguez Molas (1982), and (Slatta, 1992). A traditional view of landowners as absentee rentiers (e.g., Oddone, 1936; Giberti, 1961; Gaignard, 1989) has been substantially revised by recent literature (e.g., Hora, 2001; Sesto, 2005)
} 
a core skill in extensive cattle-raising, was historically common among Argentines of all social ranks, whereas European migrants rarely had that skill. ${ }^{16}$

The differential human capital thesis advanced by Gerchunoff and Torre (2014) is consistent with data on specialization within the primary sector by nationality. Such data is not available from the 1914 census, but it is from the 1895 census micro-data samples collected by Somoza and Lattes (1967). Among Argentine landowners, 30\% reported involvement in ranching, whereas among European ones less than 10\% did so. Similarly, among Argentine male adults working in the primary sector (including ranching and agriculture), the share in ranching was $32 \%$, whereas among Europeans it was 13\%.

The contrast in specialization patterns between Argentines and Europeans was particularly stark when we consider Italians. Among these migrants the share of the pimary sector labor reporting involvement in ranching was only 3\%. For Spaniards, the other major immigrant group, this share was $29 \%$, close to the one for Argentines. This is consistent with Spain's distinct ranching orientation in continental Europe, which can be traced to medieval times (OtoPeralías, 2020).

Table 5 shows that cattle raising areas attracted less European migrants than other locations (columns 1-3). Moreover, columns 4-6 show that in ranching locations there were fewer Italians among Europeans. The results are consistent with the idea that the lower presence of Europeans, particularly Italians, in ranching areas reflected the complementarity of their skills with cereal production rather than ranching.

The larger share of Europeans in non-ranching areas may have indirectly paved the way for subsequent structural change. While Europeans did not have higher levels of literacy than Argentines in this period, they did have more skills for manufacturing and services, as Europe was very far ahead in these activities. We discuss this further in the next section.

\section{Ranching and the Process of Development}

Having shown how ranching specialization shaped local economies historically, we now analyze its effects on the process of development. We start with a brief summary of the channels

\footnotetext{
${ }^{16}$ Horses were much more abundant in Argentina, where "even beggars were said to possess horses" than in Europe, where horses were "the very emblem of aristocratic wealth, power, and status"; in Buenos Aires there were about 4.4 horses per capita in the late 19th century, while in Britain and Germany there were about 0.1 (Hora, 2001).
} 
through which ranching specialization may have influenced development. Then, we empirically examine the effects of ranching specialization on a set of key development outcomespopulation density, urbanization, industrialization, income per capita, human capital—at different points in time.

The various ways in which ranching specialization shaped local economies have relevant implications for subsequent development. Weak forward and backward linkages would imply a reduced incentive for local industrialization. Cereal production supplied milling, a dynamic activity that could in turn induce entry into related sectors. It also induced significant investments in agricultural machinery, generating opportunities by domestic producers. In contrast, the lack of linkages in cattle ranching created enclave-type economies, which would likely stifle the process of diversification. Ranching areas were also characterized by lower railroad density and thus reduced access to markets, which would also tend to hamper development.

In addition, land concentration and low population density in ranching areas implied weak demand linkages and muted agglomeration effects. This limitation was likely to interact with the absence of forward and backward linkages. Cereal producing areas not only presented significant investment opportunities in downstream and upstream activities, but also relatively large markets, dense labor pools, and diverse sets of input suppliers. All of these were lacking in ranching economies.

Finally, historical migration patterns affected the composition of skills in the population. As discussed before, European migrants were differentially attracted to non-ranching areas due to their comparative advantage for crop cultivation. As discussed in later in this section, Europeans also had skills valuable for manufacturing and services. Thus, differential migration created differential conditions for subsequent structural change.

We view the different channels examined here as complementary and do not attempt to assess quantitavely their relative importance. Besides the limitations of available data, we would not be able to conduct a proper mediation analysis with only one instrumental variable and many potentially relevant mediating variables. In the following section we examine other possible mechanisms (agricultural prices and productivity, seasonality, school funding), and do not find empirical support for them. 


\subsection{Population Density and Urbanization}

We start our study of ranching's effects on the process of development by establishing that the negative effects on population were persistent. Table 6 displays estimates of the effects of ranching specialization on population density at different points in time. We report OLS estimates (Panel A) and IV estimates (Panel B) for the specification with the full set of controls (province fixed effects, land productivity measures, and other geo-climatic controls).

The results show that there was a stable differential in density between ranching and nonranching areas, which experienced (approximately) parallel growth for 1914 onward. According to the results in column 4 , a reduction of one standard deviation in ranching specialization (0.24) would lead to an increase of 0.35 standard deviations in the log of population density in 2001, which amounts to 48 log points (62\% in density levels). By comparison, Bleakley and Lin (2012) estimate that among counties in the United States being close to a historical portage site increased population in 2000 by about 77-94 log points.

\subsection{Industrialization}

Next, we examine how early specialization in cattle ranching affected structural change. The sharp fall in international demand for primary products during the Great Depression of the 1930s led to the demise of Argentina's agro-export model and the rise of import-substituting industrialization. Over the next four decades manufacturing was the fastest growing sector of the economy. Thus, understanding the effects of early ranching specialization on the manufacturing sector over this period is key to understanding its overall effects on long-run development.

Table 7 displays estimates of the effects of ranching specialization on the industrial sector. Columns 1-3 report results for three outcomes in 1947. Ranching is negatively associated with industrial value added per worker and with skill-intensity (proxied by the share of nonproduction workers in manufacturing). For our measure of the overall advance of industrialization (the share of industrial workers in the population), we find a negative coefficient in the OLS estimation but a positive one in the IV estimation. The latter estimate, which contrasts with the rest of our results on the effects of ranching on development, is largely driven by a few counties with the highest shares of the population in manufacturing at the time. ${ }^{17}$

\footnotetext{
${ }^{17}$ Dropping from the sample five or ten counties with highest values makes the coefficient much smaller and not statistically significant (while all other IV estimates remain stable). Industrialization in 1947 displays a highly skewed distribution, with very low values in most counties. The top five values — La Plata (Buenos Aires' provincial
} 
We also examine the effects of ranching on manufacturing at later time periods (column 4-5). We find large and significant negative effects of ranching on the share of the population employed in manufacturing by 1970, close to the height of the industrilization process. Finally, we consider the share of industrial workers in the labor force in 2001 and confirm that ranching specialization had significant negative effects on industrialization over the long run. ${ }^{18}$

The larger share of European migrants in non-ranching sectors may have indirectly contributed to industrialization. Europeans did not have higher average levels of literacy than Argentines in this period, but they were likely more skilled for manufacturing and services, as Europe was far ahead in these activities. This is consistent with the evidence on the role of European migrants in Argentina's economic development presented by Droller (2018). In the late 19th century and early 20th century, Europeans were over-represented in manufacturing, both in terms of ownership of establishments and employment, and they were over-represented in high-skill occupations; moreover, the presence of Europeans was conducive to human capital formation, industrialization, and higher levels of income per capita across Argentine counties in the long-run.

\subsection{Long-run Development}

In Table 8 we assess the effects of ranching specialization on long-run development. In columns 1-2 we consider proxies for income per capita and non-agricultural income per capita (in logs; see Appendix for details). For both outcomes we see significant negative effects of ranching specialization. According to the results in Panel B, column 1, a reduction of one standard deviation (0.24) in ranching specialization in 1914 would have led to an increase of 0.52 standard deviations in the log of income per capita in 1994, which amounts to 59 log points $(80 \%$ in income per capita levels).

Next, we examine two measures of human capital formation: years of schooling and the share of the population between 25 and 60 years of age that completed primary education. This latter measure of human capital, which has a mean of over 0.8 in our sample, is also a proxy for social inclusion. The results in columns 3-4 show negative and significant effects of ranching

capital), Rosario (Santa Fe's largest city), and three contiguous counties on the banks of the Paraná's estuary about $100 \mathrm{~km}$ north of Buenos Aires City (Zarate, Campana, and Baradero)—are above the 75th percentile by over three times the size of the interquartile range.

${ }^{18}$ We find similar results when considering the share of industrial workers in the population or considering the share on non-agricultural workers in the labor force or in the population. 
specialization on both measures of human capital in the longrun.

\subsection{Robustness}

We show here that results are robust to including addional land productivity measures in the control set, to excluding provicial capitals or urban counties, and to accounting for spatial dependence through Conley standard errors (Conley, 1999).

The identifying assumption in our IV regressions is that our measure of potential ranching specialization, based on the estimation of the FML model, only affects development outcomes through actual ranching specialization. While our identifying variation is given by variation in relative productivities among primary products, the exclusion restriction requires appropriately controlling for overall primary productivity. In our baseline analysis, we control for the mean and the first principal component of all climate-based product-specific productivity measures used in the IV construction. In Appendix Table A4 we show that the results are robust to controlling for these and other land productivity measures in flexible ways. We consider three key long-run development outcomes, and for each of them we show our baseline specification and the estimated effects of ranching specialization when we add an additional measure of land productivity (an index of land suitability for cultivation from Ramankutty et al., 2002, to be interpreted as the probability that a given area is cultivated), and when we include cubic polynomials of all of the land productivy measures. The results are consistent throughout specifications.

Appendix Table A5 shows that the estimated effects of ranching, on the same measures of long-run development, are robust to the exclusion of provincial capitals (Panel A) and the exclusion of urban counties, i.e., those with urban shares of population above 50\% (Panel B).

In Appendix Table A6 we show that inference is robust to using the heteroskedasticityautocorrelation (HAC) estimator introduced by (Conley, 1999) with bandwidths from 50 to 250 kilometers (computed with the acreg command developed by Colella et al. (2019)). The estimated effects of early ranching on long-run levels of urbanizations, income per capita, and human capital formation are significant in all specifications. 


\subsection{Discussion: Subnational Analysis versus Country-Level Analysis}

When interpreting our results and their implications, it is important to keep in mind that our analysis is based on subnational variation. Our findings about the effects of particular staples at the local economy level do not necessarily carry over to the country level. The regional and national growth of the U.S. in the first half of the 19th century is a case in point. From the perspective of local economies, Southern cotton production created little to no urbanization and favored stark levels of inequality. But at the same time, according to North (1966), the massive expansion of Southern cotton exports was a core engine of growth for the American economy, creating a vigorous demand for Northeastern manufactures as well as transportation, finance, and marketing.

Ranching's forward linkages may have been stronger from a country-wide perspective than they were at the local economy level. We stressed that ranching did not create investment opportunities in downstream industries because the meat-packing industry located near the Buenos Aires port. From the national viewpoint, though, this activity was an important outgrowth of ranching production, employing many workers (largely of European origin) and using advanced know-how, sophisticated marketing methods and large distribution networks. On the other hand, meat-processing was dominated by foreign firms, and there was little spillover to other activities.

Ranching's demand linkages may also have been stronger from a country-wide perspective than at the local level. We stressed that land concentration and income inequality likely induced a lower average propensity to consume and a higher share of luxury goods produced abroad, while investment was limited and also sourced mostly from foreign suppliers. But according to Galiani et al. (2008), the demand of high-income groups in late 19th century Argentina promoted the emergence of human-capital-intensive services. While these services developed in urban centers, demand may have partly originated in rents from ranching activites.

In contrast, other plausible mechanisms operating only at the country-wide level may have added to negative overall effects of ranching specialization. In his comparative analysis of Argentina and Canada, Solberg (1987) emphasized how Argentina's ranching specialization and land concentration hampered development through political economy mechanisms. For instance, Argentina's large and powerful landowners blocked trade policies favoring industrialization. Adamopoulos (2008) explains the divergence between Argentina and Canada along 
similar lines, proposing a formal model in which landed elites hinder industrialization through tariff policy to protect their rents. Landowners may also curtail public funding for schools, insofar as human capital is complementary to industrialization (see Galor et al., 2009). In Argentina such funding was mostly determined by the federal government, limiting the relevance of this mechanism at the local level (as further discussed later in the paper), though possibly not at the national level.

Finally, note that the magnitude of ranching's effects on long-run population density and income per capita depend on the degree of labor mobility. Without labor flows, productivity differences translate into differences in income per capita, with no effects on population density. With perfect mobility, income differentials induce labor flows, translating into differences in population density. Income differences can only remain in equilibrium if they are compensated by differential living costs and amenities. As population relocates to places with higher productivity and initially higher income per capita, congestion pushes up living costs, perhaps eroding some of the initial productivity differential (if there are decreasing returns) or reinforcing it (through agglomeration forces). While the expected effects of higher productivity on income per capita and population density go in the same direction, their magnitudes reflect not only direct impacts but also the ensuing movements toward spatial equilibrium. Given these considerations, when swtiching from a cross-county analysis to a country-level perspective, lower labor mobility would imply smaller effects on population density and larger effects on income per capita.

\section{Other channels}

In this section we assess the empirical relevance of other channels through which early ranching specialization may have affected the process of development. First, we examine whether the long-term effects of ranching specialization may reflect differences in productivity or prices among staples. Then, we examine whether the observed effects may be connected to the seasonality of different products. Finally, we examine whether land concentration associated to ranching negatively affected education through political economy mechanisms. The available data does not seem to support the relevance of these channels. 


\subsection{Agricultural Productivity and Prices}

Differences in technological progress and prices across agricultural products, combined with variation in the composition of primary production across counties, generate variation in county level agricultural income. In turn, agricultural revenues can influence the process of industrialization. This channel could partly explain the influence of agricultural production (in particular, ranching specialization) on long-run development.

Agricultural income may affect industrialization positively or negatively. On the one hand, higher agricultural productivity may release labor to be employed in manufacturing as well as increase the local demand for industrial goods (Johnston and Mellor, 1961). On the other hand, in open economies the growth of primary productivity or international prices would shift comparative advantage against manufacturing (Matsuyama, 1992).

We examine whether differences in the composition of agricultural production at the county level influenced industrialization as they entailed differences in physical productivity or revenues of the local agricultural sector. To do so, we consider variation across agricultural products in technological progress as well as in export prices.

First, we estimate the effects of initial levels and subsequent increases in potential agricultural productivity. Initial levels are captured by our baseline controls for agricultural productivity, based on FAO-GAEZ yields for intermediate levels of technology. We consider the gap between our baseline measure of mean potential productivity and the analogous one based on FAO-GAEZ yields for advanced technology, capturing potential productivity increases in more recent decades. Appendix Table A7 shows that there is no evidence that either productivity levels nor their growth significantly affected the process of industrialization.

Second, we examine the effect of differences in agricultural revenues across counties by considering differences in the product mix of each county and the evolution of export prices. More precisely, we construct a yearly predicted price index for each county's agricultural output between 1914 and 2001. For each year, we interact the export prices for beef, corn, and wheat with the corresponding land shares in 1914. While we do not have historical price data for other products, land shares for ranching, corn and wheat added together represented $93 \%$ of total farmland use for the median county in our sample, and over 80\% for almost 9 in 10 counties. $^{19}$

\footnotetext{
${ }^{19}$ We rescale the shares of the three products with available data by their added total, so that the rescaled shares add up to one for each county; this is equivalent to assuming that the price corresponding to the share for all other products evolves just like the combined share of the three products with price data. We normalize all export prices
} 
With these yearly measures, we calculate the average predicted price index for 1914-1947, 19141970, and 1914-2001, and (to capture volatility) the coefficient of variation for the same three periods.

In Appendix Table A8, we repeat the regressions for industrialization in 1947, 1970, and 2001 including the average predicted price indexes and their coefficients of variation in the corresponding periods. We do not find statistically significant coefficients for these new variables. In contrast, the estimated coefficients for initial ranching specialization remain negative in all cases and statistically significant in most of the cases.

\subsection{Seasonality}

Earle and Hoffman (1980) point out that wheat, corn, and livestock had highly seasonal labor requirements, which also lowered labor costs for the industrial sector. Sokoloff and Dollar (1997) also emphasize the high seasonality of grains, but they argue that the availability of cheap seasonal labor could hinder the adoption of more efficient manufacturing technologies.

To assess whether the long-run effects of ranching may be connected to different patterns of seasonality in primary production, we rely on the fact that wheat was the most seasonal crop among grains (Sokoloff and Dollar, 1997; Free, 1938). In Appendix Table A9, we include the share of wheat in farmland as a control. Taking into account the differential seasonality within grains, we would expect that if seasonality played a relevant role, the coefficient on the wheat share would be significant and we would find a lower coefficient for ranching specialization. However, we find that the coefficient on ranching remains stable when controlling for the wheat share, while the coefficient on the wheat share itself is not significant.

\subsection{Education}

Ranching specialization may have negatively affected human capital formation through land concentration. As established by previous work, land concentration may retard the emergence of human capital promoting institutions (Galor et al., 2009). ${ }^{20}$ The main logic is that powerful landed elites may have incentives to hamper finance for public schools insofar as human capital

to 1 in 1914 before calculating the price indexes.

${ }^{20}$ Galor et al. (2009) provide a panel data analysis at the US state-level from 1880 to 1940 showing that concentration in land ownership had a significant adverse effect on educational expenditures. Ramcharan (2010) and Vollrath (2013) provide evidence to the same effect from US county-level data during the same period. 
is complementary to industrial capital.

The evidence, however, does not support the relevance of this channel across Argentine counties. Local landed interests had limited influence in the local supply of schooling, since school funding came mostly from higher levels of government. Appendix Table A10 shows that ranching localities actually had more schools per capita in 1914 (column 1), as a higher density of public schools (column 2) more than offset a lower density of private schools (column 4). Column 5 shows that there was no significant association between ranching and enrollment rates. While the negative association between land concentration and schooling emphasized in the previous literature may have been relevant at the national level, it did not hold at the county level.

In sum, ranching areas did not have initially lower levels of human capital. The lower share of Europeans in these areas did not significantly change the picture in terms of literacy, since their levels were broadly comparable to those of Argentines in this period. ${ }^{21}$ But Europeans did have skills that were instrumental for the development of manufacturing, and this may have played an important role starting in the 1930s, when industrialization took off.

\section{Conclusion}

Using climate-based exogenous variation in primary production patterns within the Argentine Pampas, we show that ranching localities historically had weaker linkages, higher levels of land concentration, lower population density and fewer European migrants. Moreover, ranching locations remained less dense and less urbanized throughout the 20th century and experienced more sluggish industrialization. Ultimately, ranching had negative long-run effects on income per capita and education. Our findings show that early patterns of production can have a crucial influence on development patterns, providing suggestive support to the staple theory of economic growth.

We link the long-run economic performance of local economies to their specialization patterns during a period of rapid growth led by primary exports in the late 1800s and early 1900s. Some of the forces we identify may also be relevant to understand the national level growth trajectory, since Argentina as a whole was characterized by ranching specialization, limited diver-

\footnotetext{
${ }^{21}$ Italian and Spanish immigrants had higher literacy rates than Argentines among men and lower for women. European migrants from other origins did have higher literacy rates, but Italian and Spanish migrants were far more numerous than any others.
} 
sification into related activities, land ownership concentration, and low population density. Our findings echo Solberg (1987)'s comparative analysis of Argentina and Canada, which Watkins (1993) bluntly summarized: "wheat is a much better staple than meat." That country-level comparative analysis also emphasized the negative effects of ranching and land concentration in Argentina, though it centered more on political mechanisms than our subnational analysis focused on economic linkages.

Of course, findings based on subnational analysis cannot be directly extrapolated to country level analysis. As we discussed, various relevant forces at the national level may operate across rather than within the boundaries of local economies, amplifying or offsetting the negative local effects that we identify. A country level analysis of the effects of ranching would require additional data and empirical analysis to examine those cross-location spillovers, ideally through the lens of a quantitative general equilibrium model (see, e.g. Fajgelbaum and Redding, 2014; Eckert and Peters, 2018; Méndez-Chacón and Van Patten, 2019). It is important to note that even if there were positive cross-location spillovers that offset the negative county level effects, insofar as variation in ranching shaped the distribution of population and economic activity, there could be important aggregate implications in the presence of path-dependence and multiple equilibria (see Allen and Donaldson, 2020).

Our results on the importance of primary products in the process of development may have broader implications for the macro-development literature. Focusing on the relatively simple context of highly specialized agricultural economies, we provide clear-cut evidence that the composition of production can influence the growth process through various sorts of linkages. Our paper suggests that is important to study the role of linkages in the growth process over the long run, calling for models of structural change with finer levels of aggregation than standard two- or three-sector frameworks. 


\section{References}

Adamopoulos, T. (2008). Land inequality and the transition to modern growth, Review of Economic Dynamics 11(2): 257-282.

Allen, T. and Donaldson, D. (2020). Persistence and path dependence in the spatial economy, Technical report, National Bureau of Economic Research.

Altman, M. (2003). Staple theory and export-led growth: constructing differential growth, Australian Economic History Review 43(3): 230-255.

Baldwin, R. E. (1956). Patterns of development in newly settled regions, The Manchester School 24(2): 161179.

Bartelme, D. and Gorodnichenko, Y. (2015). Linkages and economic development, NBER Working Paper No. 21251 .

Bil, D. (2009a). La industria argentina de maquinaria agrícola, 1870-1975: evolución y problemas de su desarrollo, Documentos de Jovenes Investigadores no. 16 .

Bil, D. (2009b). Mercado y Fabricacaón de Maquinaria e Implementos Agrícolas en la Argentina (18701940), Cuadernos de Historia, Serie Economia y Sociedad 11: 7-32.

Bleakley, H. and Lin, J. (2012). Portage and path dependence, Quarterly Journal of Economics 127(2): 587644.

Bruhn, M. and Gallego, F. A. (2012). Good, bad, and ugly colonial activities: do they matter for economic development?, Review of Economics and Statistics 94(2): 433-461.

Bustos, P., Caprettini, B. and Ponticelli, J. (2016). Agricultural productivity and structural transformation: Evidence from brazil, American Economic Review 106(6): 1320-1365.

Cai, J. and Li, N. (2019). Growth through inter-sectoral knowledge linkages, Review of Economic Studies 86(5).

Campi, M. (2012). Tierra, tecnología e innovación: el desarrollo agrario pampeano en el largo plazo, 1860-2007, Prometeo Libros.

Caves, R. (1971). Export-led growth and the new economic history, in Jagdish N. Bhagwati et al. (Eds.),Trade, balance of payments and growth pp. 403-442.

Caves, R. E. and Holton, R. H. (1959). The Canadian economy: Prospect and retrospect, Vol. 112, Harvard University Press.

Colella, F., Lalive, R., Sakalli, S. O. and Thoenig, M. (2019). Inference with arbitrary clustering, IZA Discussion Paper No. 12584 106(5): 61-67.

Comision Nacional del Censo (1909). Censo Agropecuario Nacional. La Ganaderia y la Agricultura en 1908, Talleres de Publicaciones de la Oficina Metereologica Nacional.

Comision Nacional del Censo (1916-1919). Tercer Censo Nacional, Talleres graficos de L.J. Rosso.

Conde, R. C. (1966). Cambios históricos en la estructura de la producción agropecuaria en la argentina utilización de los recursos, Desarrollo Económico pp. 493-509.

Conley, T. G. (1999). GMM estimation with cross sectional dependence, Journal of econometrics 92(1): 1-45.

Cortés Conde, R. (1968). Algunos rasgos de la expansión territorial en Argentina en la segunda mitad del siglo XIX, Desarrollo económico pp. 3-29.

Dell, M. and Olken, B. A. (2020). The Development Effects of the Extractive Colonial Economy: The 
Dutch Cultivation System in Java, Review of Economics Studies 87(1).

Della Paolera, G. and Gallo, E. (2003). Epilogue: the argentine puzzle, in D. Paolera and Taylor (eds), $A$ new economic history of Argentina, Vol. 1, Cambridge University Press, p. 369.

Di Tella, G. and Zymelman, M. (1973). Las etapas del desarrollo económico argentino, Editorial Paidos.

Diaz Alejandro, C. F. (1970). Essays on the economic history of the Argentine Republic, Yale University Press.

Droller, F. (2018). Migration, population composition and long run economic development: Evidence from settlements in the pampas, The Economic Journal 128(614): 2321-2352.

Dyster, B. (1979). Argentine and australian development compared, Past E Present (84): 91-110.

Earle, C. and Hoffman, R. (1980). The Foundation of the Modern Economy: Agriculture and the Costs of Labor in the United States and England, 1800-60, The American Historical Review 85(5): 1055-1094.

Eberhardt, M. and Vollrath, D. (2016). The effect of agricultural technology on the speed of development, World Development .

Eckert, F. and Peters, M. (2018). Spatial structural change, Unpublished Manuscript .

Ellison, G., Glaeser, E. L. and Kerr, W. R. (2010). What Causes Industry Agglomeration? Evidence from Coagglomeration Patterns, American Economic Review 100: 1195-1213.

Engerman, S. L. and Sokoloff, K. L. (2002). Factor Endowments, Inequality, and Paths of Development Among New World Economics, NBER Working Paper No. 9259.

Engerman, S. and Sokoloff, K. (1997). Factor Endowments, Institutions, and Differential Paths of Growth Among New World Economies, How Latin America Fell Behind: Essays on the Economic Histories of Brazil and Mexico, 1800-1914 89: 260.

Fajgelbaum, P. and Redding, S. J. (2014). External integration, structural transformation and economic development: Evidence from argentina 1870-1914, NBER Working Paper No. 20217.

Ferreres, O. J. et al. (2005). Dos siglos de economía argentina (1810-2004): historia argentina en cifras, Fundación Norte y Sur:

Free, B. J. (1938). Seasonal employment in agriculture, US Government Printing Office.

Gaignard, R. (1989). La Pampa argentina: ocupación, poblamiento, explotación: de la conquista a la crisis mundial (1550-1930), Solar, Buenos Aires.

Galiani, S., Heymann, D., Dabus, C. and Tohmé, F. (2008). On the emergence of public education in land-rich economies, Journal of Development Economics 86(2): 434-446.

Gallo, E. (n.d.). Agrarian expansion and industrial development in argentina, 1880-1930, Latin American Affairs, Oxford University Press.

Galor, O., Moav, O. and Vollrath, D. (2009). Inequality in Landownership, the Emergence of HumanCapital Promoting Institutions, and the Great Divergence, The Review of Economic Studies 76(1): 143179.

Gebhardt, R. C. (2000). River plate meat industry since c. 1900: Technology, ownership, international trade regimes and domestic policy, PhD thesis, London School of Economics and Political Science.

Geller, L. (1970). El crecimiento industrial argentino hasta 1914 y la teoría del bien primario exportable, El Trimestre Económico 37(148 (4): 763-811.

Gerchunoff, P. and Torre, I. (2014). ¿ estaba la población argentina en el lugar equivocado? un enfoque de economía política sobre las migraciones (1880-1914), Desarrollo Económico pp. 35-62.

Giberti, H. (1961). Historia económica de la ganadería argentina, Solar. 
Goldin, C. and Sokoloff, K. (1984). The relative productivity hypothesis of industrialization: The American case, 1820 to 1850, Quarterly Journal of Economics 99(3): 461-487.

Gollin, D. (2010). Agricultural productivity and economic growth, Handbook of agricultural economics 4: 3825-3866.

Hanlon, W. W. and Miscio, A. (2017). Agglomeration: A long-run panel data approach, Journal of Urban Economics 99: 1 - 14 .

Hausmann, R. and Hidalgo, C. A. (2011). The network structure of economic output, Journal of Economic Growth 16(4): 309-342.

Hirschman, A. O. (1958). The strategy of economic development, Yale University Press.

Hirschman, A. O. (1977). A generalized linkage approach to development, with special reference to staples, Economic development and cultural change 25: 67.

Hora, R. (2001). The landowners of the Argentine pampas: A social and political history 1860-1945, Clarendon Press.

IIASA/FAO (2012). Global Agro-ecological Zones (GAEZ v3.0), IIASA, Laxenburg, Austria and FAO, Rome, Italy.

Innis, H. A. (1930). The fur trade in Canada: An introduction to Canadian economic history, University of Toronto Press.

Innis, H. A. (1940). The cod fisheries: the history of an international economy, Yale University Press.

Johnston, B. F. and Mellor, J. W. (1961). The role of agriculture in economic development, American Economic Review 51(4): 566-593.

Jones, C. I. (2011). Intermediate goods and weak links in the theory of economic development, American Economic Journal: Macroeconomics pp. 1-28.

Kornblihtt, J. (2013). Los empresarios molineros argentinos ante los límites de las exportaciones harineras a principios de siglo xx,H-industri@: Revista de historia de la industria, los servicios y las empresas en América Latina (6): 1.

Kuntz-Ficker, S. and Rayes, A. (2017). The contribution of argentine exports to the economy, 1875-1929, in Kuntz-Ficker (ed.), The First Export Era Revisited, Springer, pp. 37-72.

League of Nations (1942). The Network of Wrold Trade, League of Nations.

Lluch, A. and Rayes, A. (2013). Empresas frigoríficas extranjeras y exportaciones argentinas de carnes, 1890-1930, X Coloquio de Historia de Empresas .

Martino, A. and Delgado, M. (1977). La maquinaria en la agricultura. santa fe (1880-1890), Separata del IV Congreso Nacional y Regional de Historia Argentina .

Martiren, J. L. and Rayes, A. (2016). La industria argentina de harina de trigo en el cambio de siglo. Límites y alcances, 1880-1914, H-industri@: Revista de historia de la industria, los servicios y las empresas en América Latina (18): 1-27.

Matsuyama, K. (1992). Agricultural productivity, comparative advantage, and economic growth, Journal of Economic Theory 58(2): 317-334.

McCarty, J. W. (1964). The staple approach in australian economic history, Business Archives and History 4(1): 1-22.

McCarty, J. W. (1973). Australia as a region of recent settlement in the nineteenth century, Australian Economic History Review 13(2): 148-167. 
Méndez-Chacón, E. and Van Patten, D. (2019). Multinationals, monopsony and local development: Evidence from the united fruit company, Unpublished Manuscript .

Minnesota Population Center (2020). Integrated public use microdata series, international: Version 7.3 [dataset]. https://doi.org/10.18128/d020.v7.3, Minneapolis: IPUMS, 2020.

Mullahy, J. (2015). Multivariate fractional regression estimation of econometric share models, Journal of Econometric Methods 4(1): 71-100.

North, D. (1966). The economic growth of the United States 1790-1860, WW Norton.

North, D. C. (1955). Location theory and regional economic growth, Journal of political economy 63(3): 243258.

Nunn, N. (2008). Slavery, Inequality, and Economic Development in the Americas, Harvard University Press.

Nunn, N. and Puga, D. (2012). Ruggedness: The blessing of bad geography in africa, Review of Economics and Statistics 94(1): 20-36.

Nunn, N. and Qian, N. (2011). The potato's contribution to population and urbanization: evidence from a historical experiment., Quarterly Journal of Economics 126(2): 593-650.

Nurkse, R. (1954). International investment to-day in the light of nineteenth-century experience, The Economic Journal 64(256): 744-758.

Oddone, J. (1936). La burguesía terrateniente argentina, Editiones Populares Argentinas.

Ortiz, R. M. (1978). Historia económica de la Argentina, Plus Ultra.

Oto-Peralías, D. (2020). Frontiers, warfare and economic geography: The case of spain, Journal of Development Economics 146.

Palacio, J. M. (2002). La estancia mixta y el arrendamiento agrícola: Algunas hipótesis sobre su evolución histórica en la región pampeana, 1880-1945, Boletín del Instituto de Historia Argentina y Americana Dr. Emilio Ravignani (25): 37-87.

Perez, S. (2018). Railroads and the rural to urban transition: Evidence frmo 19th-century argentina, Technical report.

Ramalho, E. A., Ramalho, J. J. and Murteira, J. M. (2011). Alternative estimating and testing empirical strategies for fractional regression models, Journal of Economic Surveys 25(1): 19-68.

Ramankutty, N., Foley, J. A., Norman, J. and McSweeney, K. (2002). The global distribution of cultivable lands: current patterns and sensitivity to possible climate change, Global Ecology and Biogeography 11(5): 377-392.

Ramcharan, R. (2010). Inequality and redistribution: Evidence from US counties and states, 1890-1930, The Review of Economics and Statistics 92(4): 729-744.

Randle, P. H. (1981). Atlas del desarrollo territorial de la ArgentinaMemoria, Oikos.

Rayes, A. (2015). La estadística de las exportaciones argentinas, 1875-1913. nuevas evidencias e interpretaciones, Investigaciones de Historia Económica-Economic History Research 11(1): 31-42.

Regalsky, A. and Jáuregui, A. (2012). Comercio exterior, mercado interno e industrialización: el desarrollo de la industria láctea argentina entre las dos guerras mundiales. actores y problemas, Desarrollo Económico: Revista de Ciencias Sociales pp. 493-527.

Rocchi, F. (2005). Chimneys in the desert: industrialization in Argentina during the export boom years, 18701930, Stanford University Press.

Rodríguez Molas, R. (1982). Historia social del gaucho, Buenos Aires: Centro Editor de América Latina . 
Schedvin, C. B. (1990). Staples and regions of pax britannica, Economic History Review pp. 533-559.

Scobie, J. R. (1964). Revolution on the Pampas: A Social History of Argentine Wheat, 1860-1910, Vol. 1, University of Texas Press.

Sesto, C. (2005). Historia del capitalismo agrario pampeano. La vanguardia ganadera bonaerense, 1856-1900, Siglo XXI Editores.

Slatta, R. W. (1992). Gauchos and the vanishing frontier, University of Nebraska Press.

Slutzky, D. (1968). Aspectos sociales del desarrollo rural en la pampa húmeda argentina, Desarrollo económico pp. 95-135.

Sokoloff, K. L. and Dollar, D. (1997). Agricultural Seasonalily and the Organization of Manufacturing in Early Industrial Economies: The Contrast Between England and the United States, Journal of Economic History 57(02): 288-321.

Solberg, C. E. (1987). The prairies and the pampas: agrarian policy in Canada and Argentina, 1880-1930, Stanford University Press.

Somoza, J. and Lattes, A. (1967). Muestras de los dos primeros censos nacionales de población, 1869 y 1895, Instituto Torcuato Di Tella, Centro de Investigaciones Sociales, Documento de Trabajo 46.

Talhelm, T., Zhang, X., Oishi, S., Shimin, C., Duan, D., Lan, X. and Kitayama, S. (2014). Large-scale psychological differences within china explained by rice versus wheat agriculture, Science 344(6184): 603608.

Taylor, A. M. (2018). The argentina paradox: microexplanations and macropuzzles, Latin American Economic Review 27(1): 3.

Tornquist, E. (1919). The economic development of the Argentine Republic in the last fifty years, Ernesto Tornquist \& Company.

Vollrath, D. (2011). The agricultural basis of comparative development, Journal of Economic Growth 16(4): 343-370.

Vollrath, D. (2013). Inequality and school funding in the rural United States, 1890, Explorations in Economic History 50(2): 267-284.

Watkins, M. (1993). Wheat as a staple, The Prairies and the Pampas: A Review Colloquium on The Prairies and the Pampas: Agrarian Policy in Canada and Argentina, 1880-1930, by Carl E. Solberg, Vol. 67, pp. 279-299.

Watkins, M. H. (1963). A staple theory of economic growth, Canadian Journal of Economics and Political Science/Revue canadienne de economiques et science politique 29(2): 141-158.

Williamson, J. G. (1980). Greasing the wheels of sputtering export engines: Midwestern grains and american growth, Explorations in Economic History 17(3): 189.

Winn, P. (1976). British informal empire in uruguay in the nineteenth century, Past \& Present (73): 100-126.

Wooldridge, J. M. (2010). Econometric analysis of cross section and panel data, MIT press. 


\section{Figures}

Figure 1: Ranching specialization, 1914

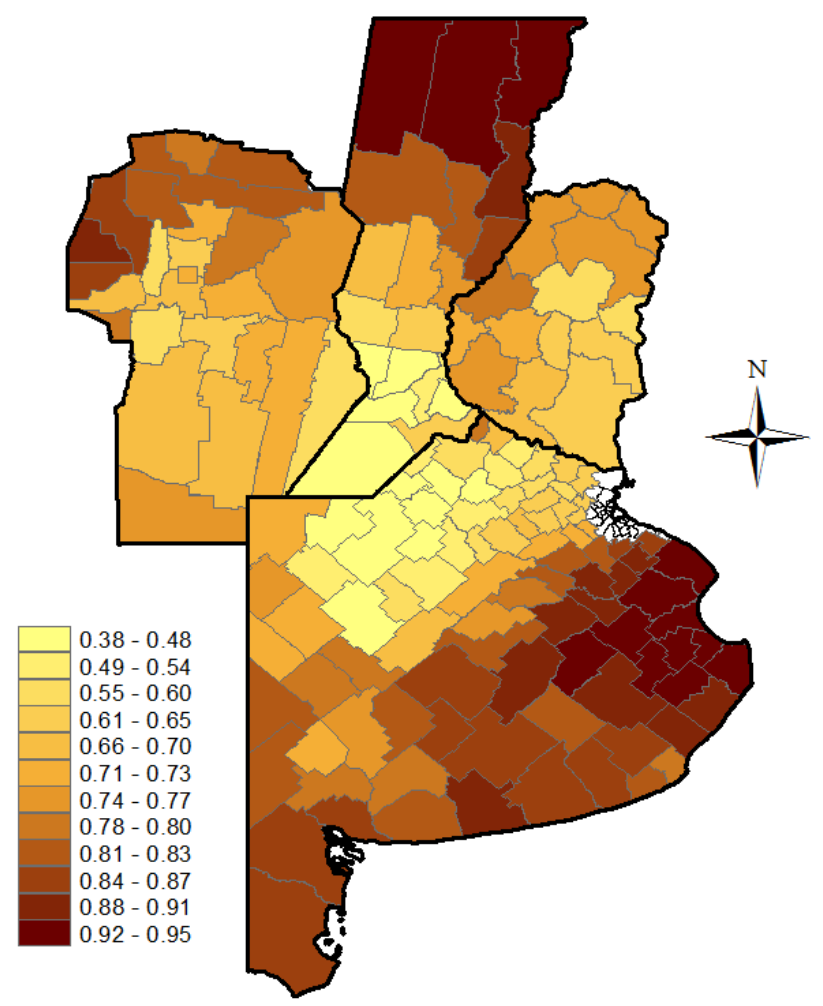

Notes: The map displays the county-level shares of agricultural land corresponding to ranching activity. 
Figure 2: Potential Yields for Key Crops
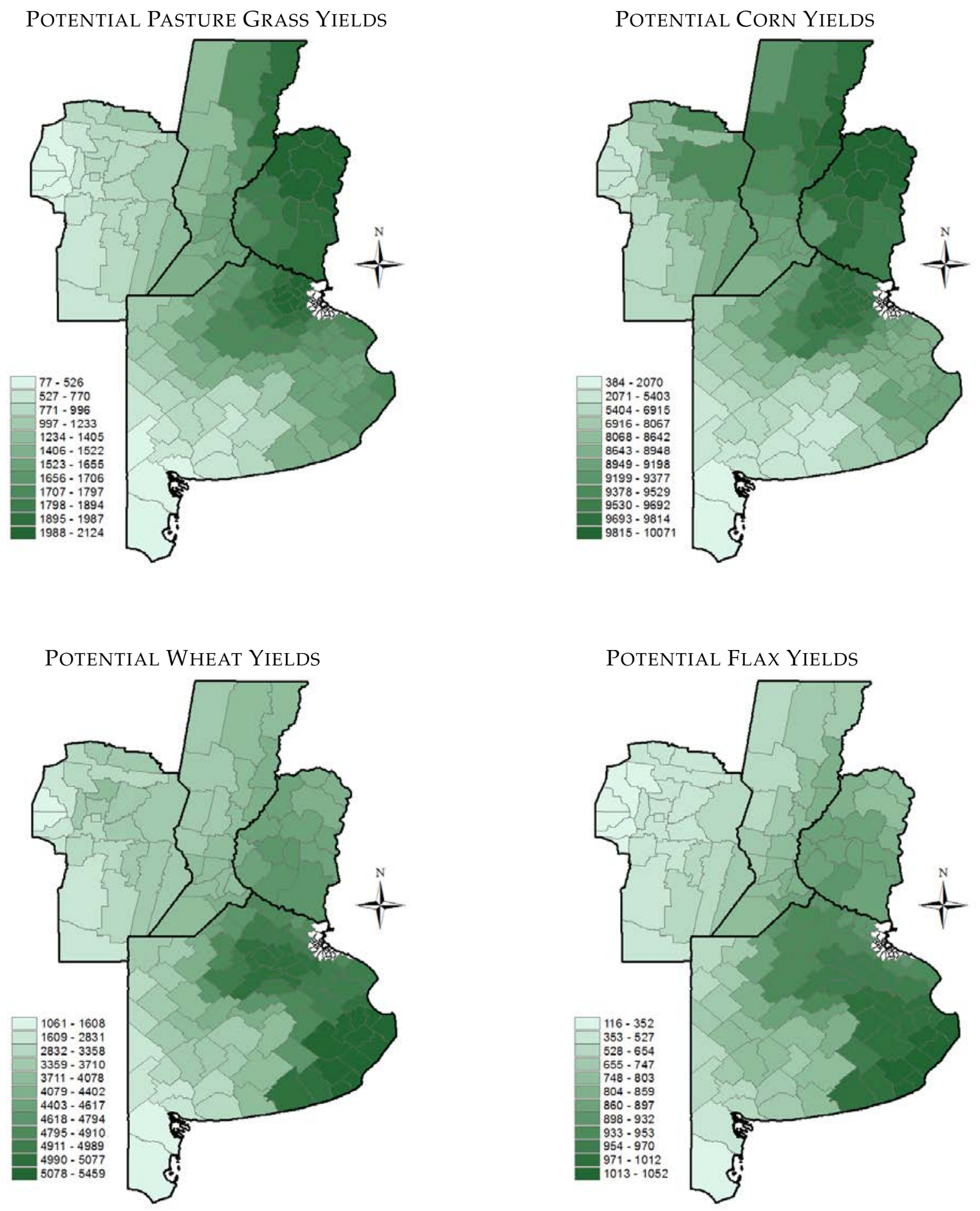

Notes: The maps displays county-level means of agro-climatic attainable yields from IIASA/FAO (2012) for pasture grass, corn, wheat, and flax in tons per hectare per year for rain-fed conditions and intermediate levels of inputs/technology. 
Figure 3: Actual and Potential Ranching Specialization

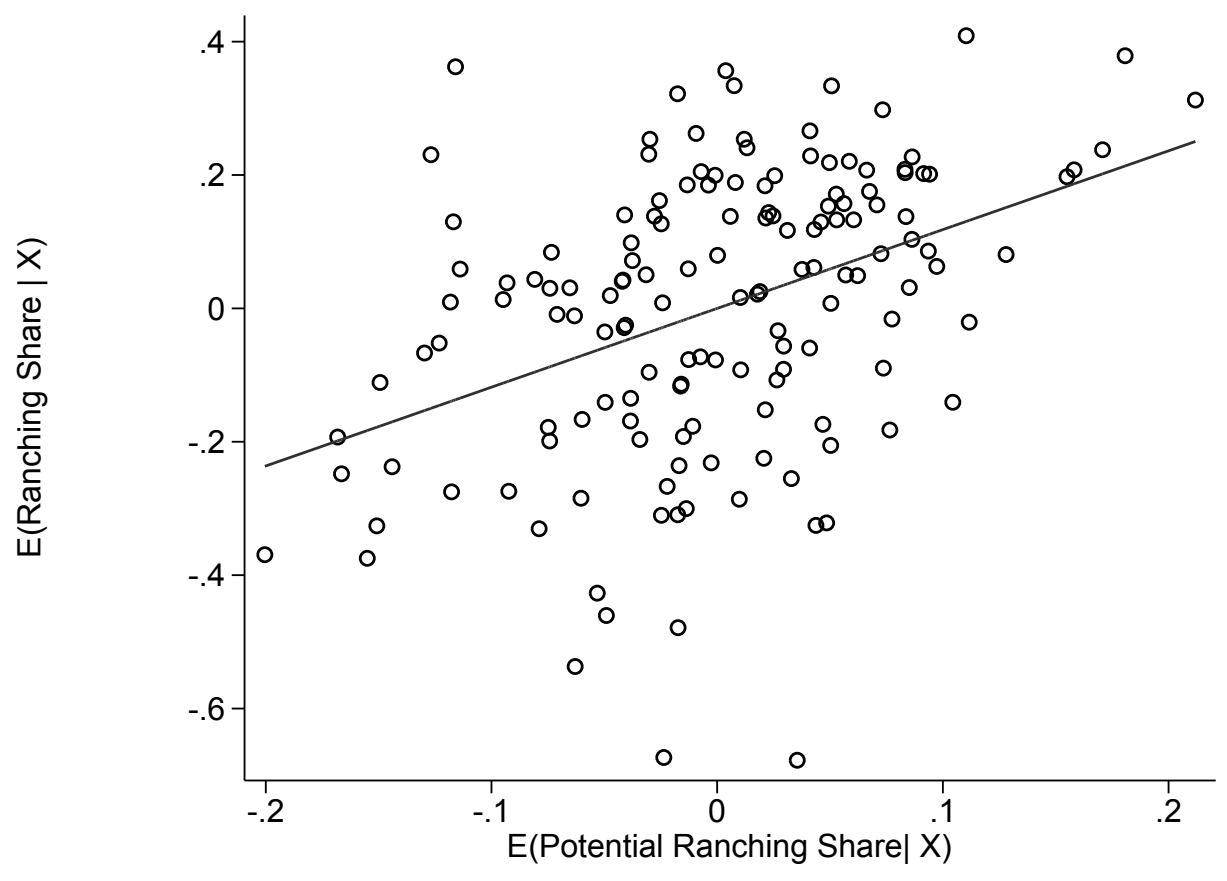

Notes: The figure displays a scatter plot of the actual and predicted shares of ranching land in total agricultural land (obtained from the FML model), partialling out province fixed effects, land suitability measures and geo-climatic controls. 


\section{Tables}

Table 1: Land Use Shares (1914)

\begin{tabular}{lcccc}
\hline \hline Land use & Mean & Std. Dev. & Min & Max \\
\hline Ranching & 0.723 & 0.242 & 0.000 & 0.998 \\
Corn & 0.104 & 0.157 & 0.000 & 0.662 \\
Wheat & 0.085 & 0.110 & 0.000 & 0.505 \\
Flaxseed & 0.038 & 0.058 & 0.000 & 0.246 \\
Oats & 0.021 & 0.032 & 0.000 & 0.222 \\
Alfalfa & 0.013 & 0.029 & 0.000 & 0.310 \\
Forest & 0.006 & 0.032 & 0.000 & 0.344 \\
Others & 0.009 & 0.022 & 0.000 & 0.212 \\
\hline \hline
\end{tabular}

Notes: The table displays the mean, standard deviation, minimum and maximum values of the shares of total farm land by product for the counties in our sample.

Table 2: Backward Linkages

\begin{tabular}{lcccccc}
\hline \hline \multirow{2}{*}{ Dependent Variable: } & \multicolumn{2}{c}{ Ln Farm capital Intensity (1914) } & \multicolumn{3}{c}{ Railroad density $(1914)$} \\
& $(1)$ & $(2)$ & $(3)$ & $(4)$ & $(5)$ & $(6)$ \\
\cline { 2 - 7 } & & & & & & \\
Panel A. OLS Estimates & & & & & & \\
Ranching & $-2.942^{* * *}$ & $-2.951^{* * *}$ & $-2.723^{* * *}$ & $-6.457^{* * *}$ & $-5.903^{* * *}$ & $-5.073^{* * *}$ \\
& $(0.246)$ & $(0.221)$ & $(0.213)$ & $(1.385)$ & $(1.457)$ & $(1.336)$ \\
& & & & & & \\
$\mathrm{R}^{2}$ & 0.505 & 0.635 & 0.732 & 0.199 & 0.275 & 0.399 \\
& & & & & & \\
Panel B. IV Estimates & & & & & & \\
Ranching & $-3.929^{* * *}$ & $-4.109^{* * *}$ & $-4.328^{* * *}$ & $-6.609^{* * *}$ & $-6.131^{* * *}$ & $-7.339^{* * *}$ \\
& $(0.707)$ & $(0.517)$ & $(0.543)$ & $(1.952)$ & $(1.870)$ & $(2.321)$ \\
& & & & & & \\
$\mathrm{R}^{2}$ & 0.449 & 0.562 & 0.612 & 0.199 & 0.275 & 0.380 \\
Number of Counties & 150 & 150 & 150 & 150 & 150 & 150 \\
Mean of Dependent Variable & 1.64 & 1.64 & 1.64 & 4.09 & 4.09 & 4.09 \\
& & & & & & \\
State Fixed Effects & No & Yes & Yes & No & Yes & Yes \\
Land Productivity Measures & No & No & Yes & No & No & Yes \\
Geo-climatic Controls & No & No & Yes & No & No & Yes \\
\hline \hline
\end{tabular}

Notes: Farm capital intensity is defined as farm capital (value of tools, implements, and equipment) per hectare. Railroad density is defined as railroad $\mathrm{km} / 100 \mathrm{~km}^{2}$. Robust standard errors reported in parentheses. *** Significant at the $1 \%$ level; ${ }^{* *}$ Significant at the 5\% level; ${ }^{*}$ Significant at the $10 \%$ level. 
Table 3: First Stage Regressions

\begin{tabular}{lccc}
\hline \hline Dependent Variable: & \multicolumn{3}{c}{ Ranching Specialization (1914) } \\
& $(1)$ & $(2)$ & $(3)$ \\
Potential Ranching Share & $1.006^{* * *}$ & $1.212^{* * *}$ & $1.181^{* * *}$ \\
& $(0.166)$ & $(0.171)$ & $(0.187)$ \\
& & & \\
Number of Counties & 150 & 150 & 150 \\
Mean of Dependent Variable & 0.72 & 0.72 & 0.72 \\
$\mathrm{R}^{2}$ & 0.23 & 0.26 & 0.33 \\
Kleibergen-Paap Wald F-stat & 36.88 & 50.42 & 39.70 \\
& & & \\
State Fixed Effects & No & Yes & Yes \\
Land Productivity Measures & No & No & Yes \\
Geo-climatic Controls & No & No & Yes \\
\hline \hline
\end{tabular}

Notes: Robust standard errors reported in parentheses. $* *$ Significant at the $1 \%$ level; ** Significant at the $5 \%$ level; * Significant at the $10 \%$ level. 
Table 4: Land Concentration and Labor Intensity

\begin{tabular}{|c|c|c|c|c|c|c|c|c|c|}
\hline \multirow{3}{*}{ Panel A. OLS Estimates } & \multicolumn{3}{|c|}{ Land Concentration (1914) } & \multicolumn{3}{|c|}{ Ln Population Density (1914) } & \multicolumn{3}{|c|}{ Urban Population Share (1914) } \\
\hline & \multicolumn{2}{|c|}{ (1) (2) } & $\begin{array}{c}n(1914) \\
(3)\end{array}$ & \multicolumn{2}{|c|}{ (4) } & \multirow[t]{2}{*}{$(6)$} & \multirow{2}{*}{\multicolumn{2}{|c|}{$(7) \quad(8)$}} & \multirow[t]{2}{*}{ (9) } \\
\hline & & & & & & & & & \\
\hline Ranching & $\begin{array}{c}0.679^{* * *} \\
(0.050)\end{array}$ & $\begin{array}{c}0.706^{* * *} \\
(0.054)\end{array}$ & $\begin{array}{c}0.684^{* * *} \\
(0.063)\end{array}$ & $\begin{array}{c}-2.477^{* * *} \\
(0.277)\end{array}$ & $\begin{array}{c}-2.603^{* * *} \\
(0.292)\end{array}$ & $\begin{array}{c}-2.399^{* * *} \\
(0.272)\end{array}$ & $\begin{array}{c}-0.237^{* * *} \\
(0.074)\end{array}$ & $\begin{array}{c}-0.255^{* * *} \\
(0.072)\end{array}$ & $\begin{array}{c}-0.205^{* *} \\
(0.079)\end{array}$ \\
\hline $\mathrm{R}^{2}$ & 0.518 & 0.539 & 0.789 & 0.370 & 0.395 & 0.590 & 0.080 & 0.162 & 0.220 \\
\hline \multicolumn{10}{|l|}{ Panel B. IV Estimates } \\
\hline Ranching & $\begin{array}{c}0.458^{* * *} \\
(0.105)\end{array}$ & $\begin{array}{c}0.593^{* * *} \\
(0.111)\end{array}$ & $\begin{array}{c}0.897^{* * *} \\
(0.080)\end{array}$ & $\begin{array}{c}-1.901^{* * *} \\
(0.555)\end{array}$ & $\begin{array}{c}-2.173^{* * *} \\
(0.618)\end{array}$ & $\begin{array}{c}-2.553^{* * *} \\
(0.549)\end{array}$ & $\begin{array}{c}-0.152 \\
(0.156)\end{array}$ & $\begin{array}{l}-0.227 \\
(0.139)\end{array}$ & $\begin{array}{c}-0.190 \\
(0.151)\end{array}$ \\
\hline $\mathrm{R}^{2}$ & 0.463 & 0.525 & 0.748 & 0.350 & 0.385 & 0.589 & 0.070 & 0.161 & 0.219 \\
\hline Number of Counties & 150 & 150 & 150 & 150 & 150 & 150 & 150 & 150 & 150 \\
\hline Mean of Dependent Variable & 0.51 & 0.51 & 0.51 & 1.70 & 1.70 & 1.70 & 0.34 & 0.34 & 0.34 \\
\hline State Fixed Effects & No & Yes & Yes & No & Yes & Yes & No & Yes & Yes \\
\hline Land Productivity Measures & No & No & Yes & No & No & Yes & No & No & Yes \\
\hline Geo-climatic Controls & No & No & Yes & No & No & Yes & No & No & Yes \\
\hline
\end{tabular}

Notes: Land concentration is defined as the share of land in farms $1000+$ hectares. Robust standard errors reported in parentheses. $* * *$ Significant at the $1 \%$ 
Table 5: Immigration

\begin{tabular}{|c|c|c|c|c|c|c|}
\hline \multirow[t]{2}{*}{ Dependent Variable: } & \multicolumn{3}{|c|}{ European Population Share (1914) } & \multicolumn{3}{|c|}{ Italian Share of Europeans (1914) } \\
\hline & (1) & (2) & (3) & & (5) & (6) \\
\hline \multicolumn{7}{|l|}{ Panel A. OLS Estimates } \\
\hline Ranching & $\begin{array}{c}-0.273^{* * *} \\
(0.028)\end{array}$ & $\begin{array}{c}-0.244^{* * *} \\
(0.029)\end{array}$ & $\begin{array}{c}-0.236^{* * *} \\
(0.025)\end{array}$ & $\begin{array}{c}-0.270^{* * *} \\
(0.046)\end{array}$ & $\begin{array}{c}-0.252^{* * *} \\
(0.048)\end{array}$ & $\begin{array}{c}-0.154^{* * *} \\
(0.053)\end{array}$ \\
\hline $\mathrm{R}^{2}$ & 0.352 & 0.594 & 0.715 & 0.168 & 0.217 & 0.425 \\
\hline \multicolumn{7}{|l|}{ Panel B. IV Estimates } \\
\hline Ranching & $\begin{array}{c}-0.401^{* * *} \\
(0.064)\end{array}$ & $\begin{array}{c}-0.378^{* * *} \\
(0.065)\end{array}$ & $\begin{array}{c}-0.388^{* * * *} \\
(0.057)\end{array}$ & $\begin{array}{c}-0.385^{* * *} \\
(0.101)\end{array}$ & $\begin{array}{c}-0.353^{* * *} \\
(0.116)\end{array}$ & $\begin{array}{l}-0.227^{*} \\
(0.128)\end{array}$ \\
\hline $\mathrm{R}^{2}$ & 0.275 & 0.515 & 0.628 & 0.137 & 0.194 & 0.415 \\
\hline Number of Counties & 150 & 150 & 150 & 150 & 150 & 150 \\
\hline Mean of Dependent Variable & 0.23 & 0.23 & 0.23 & 0.44 & 0.44 & 0.44 \\
\hline State Fixed Effects & No & Yes & Yes & No & Yes & Yes \\
\hline Land Productivity Measures & No & No & Yes & No & No & Yes \\
\hline Geo-climatic Controls & No & No & Yes & No & No & Yes \\
\hline
\end{tabular}

Notes: Robust standard errors reported in parentheses. ${ }^{* * *}$ Significant at the $1 \%$ level; ${ }^{* *}$ Significant at the 5\% level; * Significant at the $10 \%$ level. 
Table 6: Population Density and Urbanization

\begin{tabular}{lcccccc}
\hline \hline Dependent variable: & \multicolumn{3}{c}{ Ln Population density } & \multicolumn{3}{c}{ Urban Share } \\
& 1914 & 1947 & 1991 & 2001 & 1914 & 2001 \\
& $(1)$ & $(2)$ & $(3)$ & $(4)$ & $(5)$ & $(6)$ \\
\cline { 2 - 7 } & & & & & & \\
Panel A. OLS Estimates & $-2.399^{* * *}$ & $-2.351^{* * *}$ & $-2.507^{* * *}$ & $-2.410^{* * *}$ & $-0.205^{* *}$ & $-0.161^{* * *}$ \\
Ranching & $(0.272)$ & $(0.329)$ & $(0.430)$ & $(0.434)$ & $(0.079)$ & $(0.027)$ \\
& & & & & & \\
Number of Counties & 150 & 150 & 150 & 150 & 150 & 150 \\
Mean of Dependent Variable & 1.70 & 2.14 & 2.37 & 2.46 & 0.34 & 0.87 \\
$R^{2}$ & 0.59 & 0.53 & 0.49 & 0.49 & 0.22 & 0.43 \\
& & & & & & \\
Panel B. IV Estimates & & & & & & \\
Ranching & $-2.553^{* * *}$ & $-2.482^{* * *}$ & $-2.132^{* * *}$ & $-2.014^{* *}$ & -0.190 & $-0.255^{* * *}$ \\
& $(0.549)$ & $(0.601)$ & $(0.770)$ & $(0.788)$ & $(0.151)$ & $(0.074)$ \\
Number of Counties & 150 & 150 & 150 & 150 & 150 & 150 \\
Mean of Dependent Variable & 1.70 & 2.14 & 2.37 & 2.46 & 0.34 & 0.87 \\
$R^{2}$ & 0.59 & 0.52 & 0.48 & 0.49 & 0.22 & 0.39 \\
& & & & & & \\
State Fixed Effects & Yes & Yes & Yes & Yes & Yes & Yes \\
Land Productivity Measures & Yes & Yes & Yes & Yes & Yes & Yes \\
Geo-climatic Controls & Yes & Yes & Yes & Yes & Yes & Yes \\
\hline \hline
\end{tabular}

Notes: Robust standard errors reported in parentheses. ${ }^{* *}$ Significant at the $1 \%$ level; $* *$ Significant at the $5 \%$ level; * Significant at the $10 \%$ level. 
Table 7: Industrialization

\begin{tabular}{|c|c|c|c|c|c|}
\hline & $\begin{array}{c}\text { Ln Mfg. } \\
\text { Value Added } \\
\text { per Worker } \\
1947 \\
(1)\end{array}$ & $\begin{array}{c}\text { Skill- } \\
\text { intensity } \\
\text { in Mfg. } \\
1947 \\
(2)\end{array}$ & $\begin{array}{c}\text { Share of } \\
\text { Population } \\
\text { in Mfg. } \\
1947 \\
(3)\end{array}$ & $\begin{array}{c}\text { Share of } \\
\text { Population } \\
\text { in Mfg. } \\
1970 \\
(4)\end{array}$ & $\begin{array}{c}\text { Share of } \\
\text { Labor Force } \\
\text { in Mfg. } \\
2001 \\
(5)\end{array}$ \\
\hline $\begin{array}{l}\text { Panel A. OLS Estimates } \\
\text { Ranching }\end{array}$ & $\begin{array}{l}-0.083 \\
(0.107)\end{array}$ & $\begin{array}{l}-0.028^{* *} \\
(0.012)\end{array}$ & $\begin{array}{l}-0.023^{* *} \\
(0.012)\end{array}$ & $\begin{array}{c}-0.037^{* * *} \\
(0.010)\end{array}$ & $\begin{array}{c}-0.080^{* * *} \\
(0.019)\end{array}$ \\
\hline $\begin{array}{l}\text { Number of Counties } \\
\text { Mean of Dependent Variable } \\
\mathrm{R}^{2}\end{array}$ & 0.27 & 147 & 147 & 150 & 150 \\
\hline $\begin{array}{l}\text { Panel B. IV Estimates } \\
\text { Ranching }\end{array}$ & $\begin{array}{l}-0.439^{*} \\
(0.249)\end{array}$ & $\begin{array}{l}-0.074^{* * *} \\
(0.029)\end{array}$ & $\begin{array}{l}0.044^{* *} \\
(0.021)\end{array}$ & $\begin{array}{l}-0.027^{*} \\
(0.014)\end{array}$ & $\begin{array}{c}-0.093^{* * *} \\
(0.033)\end{array}$ \\
\hline $\begin{array}{l}\text { Number of Counties } \\
\text { Mean of Dependent Variable } \\
\mathrm{R}^{2}\end{array}$ & $\begin{array}{l}147 \\
1.67 \\
0.21\end{array}$ & $\begin{array}{l}147 \\
0.09 \\
0.13\end{array}$ & $\begin{array}{c}147 \\
0.03 \\
-0.22\end{array}$ & $\begin{array}{l}150 \\
0.05 \\
0.49\end{array}$ & $\begin{array}{l}150 \\
0.17 \\
0.45\end{array}$ \\
\hline $\begin{array}{l}\text { State Fixed Effects } \\
\text { Land Productivity Measures } \\
\text { Geo-climatic Controls }\end{array}$ & $\begin{array}{l}\text { Yes } \\
\text { Yes } \\
\text { Yes }\end{array}$ & $\begin{array}{l}\text { Yes } \\
\text { Yes } \\
\text { Yes }\end{array}$ & $\begin{array}{l}\text { Yes } \\
\text { Yes } \\
\text { Yes }\end{array}$ & $\begin{array}{l}\text { Yes } \\
\text { Yes } \\
\text { Yes }\end{array}$ & $\begin{array}{l}\text { Yes } \\
\text { Yes } \\
\text { Yes }\end{array}$ \\
\hline
\end{tabular}

Notes: Robust standard errors reported in parentheses. ${ }^{* * *}$ Significant at the $1 \%$ level; ${ }^{* *}$ Significant at the $5 \%$ level; * Significant at the $10 \%$ level. 
Table 8: Long-Run Development

\begin{tabular}{|c|c|c|c|c|}
\hline Dependent variable: & $\begin{array}{c}\text { Ln Income } \\
\text { per capita } \\
1994 \\
(1) \\
\end{array}$ & $\begin{array}{c}\text { Ln Non-Agri. } \\
\text { Inc. per capita } \\
1994 \\
(2) \\
\end{array}$ & $\begin{array}{c}\text { Years of } \\
\text { Schooling } \\
2001 \\
(3) \\
\end{array}$ & $\begin{array}{c}\text { Primary School } \\
\text { Completion } \\
2001 \\
(4) \\
\end{array}$ \\
\hline $\begin{array}{l}\text { Panel A. OLS Estimates } \\
\text { Ranching }\end{array}$ & $\begin{array}{c}-1.820^{* * * *} \\
(0.425)\end{array}$ & $\begin{array}{c}-2.623^{* * *} \\
(0.514)\end{array}$ & $\begin{array}{c}-1.364^{* * *} \\
(0.247)\end{array}$ & $\begin{array}{c}-0.101^{* * * *} \\
(0.013)\end{array}$ \\
\hline $\begin{array}{l}\text { Number of Counties } \\
\text { Mean of Dependent Variable } \\
\mathrm{R}^{2}\end{array}$ & $\begin{array}{c}150 \\
18.31 \\
0.47\end{array}$ & $\begin{array}{c}145 \\
17.29 \\
0.43\end{array}$ & $\begin{array}{l}150 \\
8.73 \\
0.47\end{array}$ & $\begin{array}{l}150 \\
0.82 \\
0.65\end{array}$ \\
\hline Panel B. IV Estimates & & & & \\
\hline Ranching & $\begin{array}{l}-2.477^{* * * *} \\
(0.679)\end{array}$ & $\begin{array}{l}-2.701^{* *} \\
(1.142)\end{array}$ & $\begin{array}{l}-2.472^{* * * *} \\
(0.557)\end{array}$ & $\begin{array}{l}-0.234^{* * * *} \\
(0.042)\end{array}$ \\
\hline $\begin{array}{l}\text { Number of Counties } \\
\text { Mean of Dependent Variable } \\
\mathrm{R}^{2}\end{array}$ & 150 & 145 & 150 & 150 \\
\hline $\begin{array}{l}\text { State Fixed Effects } \\
\text { Land Productivity Measures } \\
\text { Geo-climatic Controls }\end{array}$ & $\begin{array}{l}\text { Yes } \\
\text { Yes } \\
\text { Yes }\end{array}$ & $\begin{array}{l}\text { Yes } \\
\text { Yes } \\
\text { Yes }\end{array}$ & $\begin{array}{l}\text { Yes } \\
\text { Yes } \\
\text { Yes }\end{array}$ & $\begin{array}{l}\text { Yes } \\
\text { Yes } \\
\text { Yes }\end{array}$ \\
\hline
\end{tabular}

Notes: Robust standard errors reported in parentheses. ${ }^{* * *}$ Significant at the $1 \%$ level; ${ }^{* *}$ Significant at the $5 \%$ level; * Significant at the 10\% level. 


\section{Appendix}

\section{Additional Figures}

Figure A1: Argentine Provinces in Our Sample: Buenos Aires, Córdoba, Entre Ríos, and Santa Fe

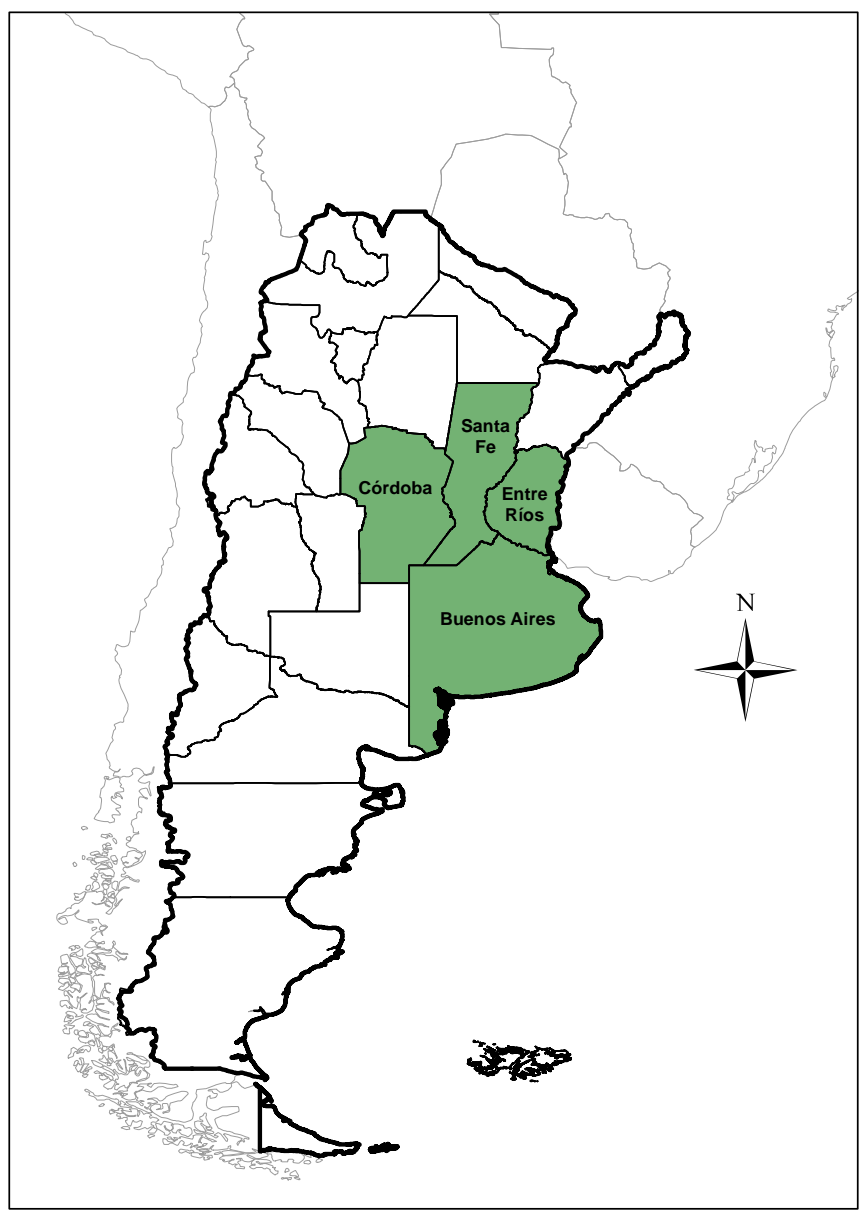


Figure A2: Long-Run Development Outcomes

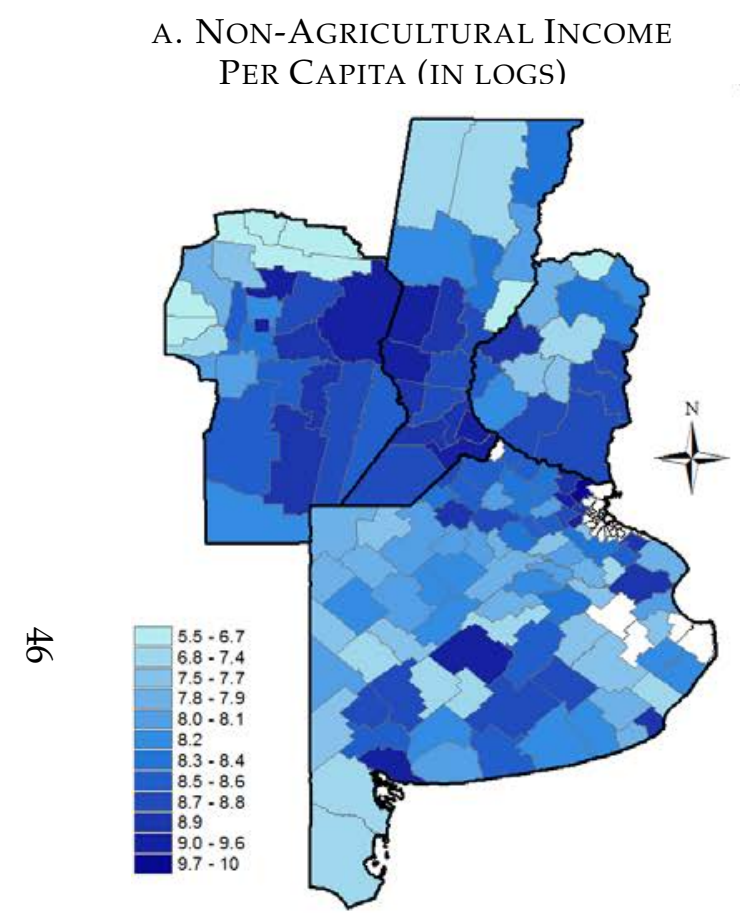

B. URBAN SHARE

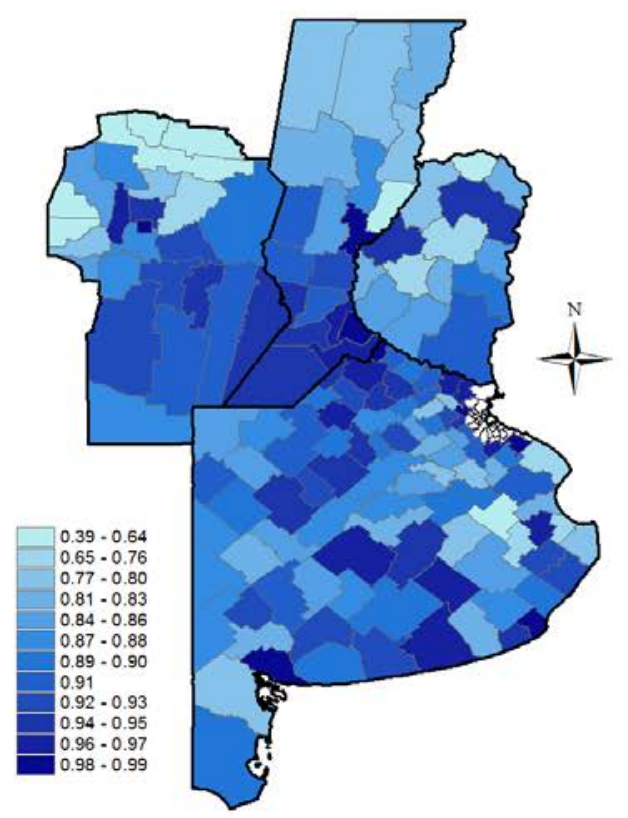

C. Average Years of Schooling

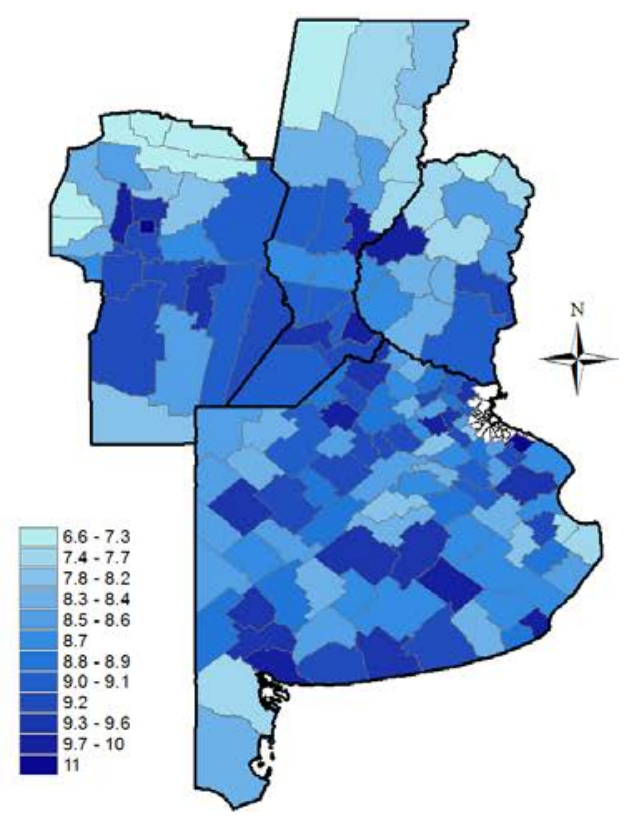

Source: See Appendix section on variable definitions and sources for details. 


\section{Additional Tables}

Table A1: Summary Statistics

\begin{tabular}{|c|c|c|c|c|}
\hline & Mean & Std Dev & Min & Max \\
\hline \multicolumn{5}{|l|}{ Land Productivity and Geo-climatic Controls } \\
\hline Mean of Crop-Specific Productivities & 0.759 & 0.178 & 0.136 & 0.934 \\
\hline First Principal Component of Crop_Specific Productivities & 0.000 & 1.850 & -6.557 & 1.795 \\
\hline Mean Annual Precipitations & 876.762 & 155.451 & 363.702 & 1219.727 \\
\hline Mean Annual Temperature & 163.157 & 16.146 & 133.600 & 204.204 \\
\hline Elevation & 131.977 & 195.087 & -1.941 & 1104.171 \\
\hline Ruggedness & 0.182 & 0.246 & 0.035 & 1.737 \\
\hline Ln Distance to Buenos Aires City & 5.644 & 0.702 & 3.823 & 6.682 \\
\hline \multicolumn{5}{|l|}{ Historical Outcomes } \\
\hline Ln Farm Capital Intensity 1914 & 1.644 & 1.000 & -2.612 & 4.117 \\
\hline Railroads Density 1914 & 4.089 & 3.494 & 0.000 & 21.701 \\
\hline Land Concentration 1914 & 0.508 & 0.228 & 0.000 & 0.993 \\
\hline Ln Population Density 1914 & 1.697 & 0.983 & -1.081 & 5.481 \\
\hline Urban Population Share 1914 & 0.340 & 0.202 & 0.000 & 0.903 \\
\hline Share of Europeans in Population 1914 & 0.229 & 0.111 & 0.001 & 0.469 \\
\hline Share of Italians Among Europeans 1914 & 0.436 & 0.159 & 0.095 & 0.864 \\
\hline Ln Population Density 1914 & 1.697 & 0.983 & -1.081 & 5.481 \\
\hline \multicolumn{5}{|l|}{ Medium-run and Long-run Outcomes } \\
\hline Ln Population Density 1947 & 2.141 & 1.025 & 0.090 & 6.534 \\
\hline Share of Population in Manufacturing 1947 & 0.028 & 0.024 & 0.004 & 0.182 \\
\hline Ln Manufacturing Valued Added per Worker & 1.672 & 0.340 & 0.628 & 2.826 \\
\hline Skill-Intensity in Manufacturing 1947 & 0.094 & 0.034 & 0.011 & 0.176 \\
\hline Share of Population in Manufacturing 1970 & 0.047 & 0.028 & 0.003 & 0.127 \\
\hline Ln Income per capita 1994 & 18.309 & 1.153 & 14.931 & 21.692 \\
\hline Ln Non-Agricultural Income per capita 1994 & 17.288 & 1.569 & 12.528 & 21.691 \\
\hline Share of Population in Manufacturing 1947 & 0.169 & 0.050 & 0.048 & 0.288 \\
\hline Ln Population Density 1991 & 2.369 & 1.335 & -0.163 & 7.649 \\
\hline Ln Population Density 2001 & 2.456 & 1.368 & -0.051 & 7.734 \\
\hline Urban Population Share 2001 & 0.869 & 0.096 & 0.392 & 0.994 \\
\hline Average Years of Schooling 2001 & 8.732 & 0.733 & 6.553 & 11.214 \\
\hline Share of Population with Completed Primary Education 2001 & 0.825 & 0.061 & 0.623 & 0.917 \\
\hline
\end{tabular}

Notes: This table reports summary statistics for the main variables used in the empirical analysis. 
Table A2: Effects of Potential Yields on Land Shares (from FML model estimation)

\begin{tabular}{lccccc}
\hline \hline Dependent variable: & $\begin{array}{c}\text { Share Ranching } \\
(1)\end{array}$ & $\begin{array}{c}\text { Share Corn } \\
(2)\end{array}$ & $\begin{array}{c}\text { Share Wheat } \\
(3)\end{array}$ & $\begin{array}{c}\text { Share Flax } \\
(4)\end{array}$ & $\begin{array}{c}\text { Share Other } \\
(5)\end{array}$ \\
\cline { 2 - 6 } & & & & & \\
Pasture Grasses potential yields & $0.578^{* * *}$ & -0.335 & $-0.419^{* * *}$ & -0.054 & 0.012 \\
& $(0.188)$ & $(0.235)$ & $(0.095)$ & $(0.076)$ & $(0.077)$ \\
Corn potential yields & $-1.970^{* * *}$ & $1.571^{* * *}$ & $0.534^{* * *}$ & $0.654^{* * *}$ & -0.090 \\
& $(0.349)$ & $(0.519)$ & $(0.141)$ & $(0.231)$ & $(0.0178)$ \\
Wheat potential yields & $2.111^{* * *}$ & $-1.539^{* * *}$ & $-0.744^{* * *}$ & $-0.396^{* * *}$ & -0.100 \\
& $(0.330)$ & $(0.552)$ & $(0.159)$ & $(0.113)$ & $(0.093)$ \\
Flax potential yields & $-1.864^{* * *}$ & $1.616^{* * *}$ & $0.605^{* * *}$ & $0.301^{* *}$ & 0.056 \\
& $(0.295)$ & $(0.544)$ & $(0.134)$ & $(0.123)$ & $(0.084)$ \\
\hline \hline
\end{tabular}

Notes: This table reports marginal effects from the estimation of the Fractional Multinomial Logit Model for land shares, calculated at the median values of the covariates and expressed as semi-elasticities (they express the change in the share of a given crop in total farmland corresponding to changes in log of potential yields for a given crop). Standard errors reported in parentheses. ${ }^{* * *}$ Significant at the $1 \%$ level; ${ }^{* *}$ Significant at the $5 \%$ level; * Significant at the $10 \%$ level.

Source: See the text and the appendix section on variable definitions and sources.

Table A3: Ranching and Railroads, controlling for Distance to the Paraná River

\begin{tabular}{lcccc}
\hline \hline \multirow{2}{*}{ Dependent Variable: } & \multicolumn{4}{c}{ Railroad Density } \\
& \multicolumn{3}{c}{ OLS Estimates } & \multicolumn{1}{c}{ IV Estimates } \\
\cline { 2 - 5 } & $(1)$ & $(2)$ & $(3)$ & $(4)$ \\
\cline { 2 - 5 } Ranching & $-5.073^{* * *}$ & $-6.393^{* * *}$ & $-7.339^{* * *}$ & $-9.388^{* * *}$ \\
& $(1.336)$ & $(1.417)$ & $(2.321)$ & $(2.684)$ \\
$\mathrm{R}^{2}$ & 0.399 & 0.434 & 0.380 & 0.406 \\
Distance to the Parana River & No & Yes & No & Yes \\
State Fixed Effects & Yes & Yes & Yes & Yes \\
Land Productivity Measures & Yes & Yes & Yes & Yes \\
Geo-climatic Controls & Yes & Yes & Yes & Yes \\
\hline \hline
\end{tabular}

Notes: Railroad density is defined as railroad $\mathrm{km} / 100 \mathrm{~km}^{2}$. Robust standard errors reported in parentheses. $* * *$ Significant at the $1 \%$ level; ${ }^{* *}$ Significant at the $5 \%$ level; ${ }^{*}$ Significant at the $10 \%$ level. 
Table A4: Additional Controls for Land Productivity

\begin{tabular}{|c|c|c|c|c|c|c|c|c|c|}
\hline & \multicolumn{3}{|c|}{ Urban Population Share 2001} & \multicolumn{3}{|c|}{ Ln. Non-Agri. Inc. per capita 1994} & \multicolumn{3}{|c|}{ Years of Schooling 2001} \\
\hline & $(1)$ & $(2)$ & $(3)$ & $(4)$ & (5) & (6) & $(7)$ & $(8)$ & $(9)$ \\
\hline $\begin{array}{l}\text { Panel A. OLS Estimates } \\
\text { Ranching }\end{array}$ & $\begin{array}{c}-0.161^{* * *} \\
(0.027)\end{array}$ & $\begin{array}{c}-0.167^{* * *} \\
(0.027)\end{array}$ & $\begin{array}{l}-0.142^{* * *} \\
(0.028)\end{array}$ & $\begin{array}{l}-2.623^{* * *} \\
(0.514)\end{array}$ & $\begin{array}{l}-2.725^{* * *} \\
(0.505)\end{array}$ & $\begin{array}{l}-2.601^{* * *} \\
(0.603)\end{array}$ & $\begin{array}{l}-1.364^{* * *} \\
(0.247)\end{array}$ & $\begin{array}{l}-1.410^{* * *} \\
(0.243)\end{array}$ & $\begin{array}{l}-1.502^{* * *} \\
(0.282)\end{array}$ \\
\hline $\begin{array}{l}\text { Number of Counties } \\
\text { Mean of Dependent Variable } \\
\mathrm{R}^{2}\end{array}$ & $\begin{array}{l}150 \\
0.87 \\
0.43\end{array}$ & $\begin{array}{l}150 \\
0.87 \\
0.46\end{array}$ & $\begin{array}{l}150 \\
0.87 \\
0.55\end{array}$ & $\begin{array}{c}145 \\
17.29 \\
0.43\end{array}$ & $\begin{array}{c}145 \\
17.29 \\
0.47\end{array}$ & $\begin{array}{c}145 \\
17.29 \\
0.48\end{array}$ & $\begin{array}{l}150 \\
8.73 \\
0.47\end{array}$ & $\begin{array}{l}150 \\
8.73 \\
0.50\end{array}$ & $\begin{array}{l}150 \\
8.73 \\
0.52\end{array}$ \\
\hline $\begin{array}{l}\text { Panel B. IV Estimates } \\
\text { Ranching }\end{array}$ & $\begin{array}{l}-0.255^{* * *} \\
(0.074)\end{array}$ & $\begin{array}{c}-0.231^{* * *} \\
(0.067)\end{array}$ & $\begin{array}{l}-0.175^{*} \\
(0.094)\end{array}$ & $\begin{array}{l}-2.701^{* *} \\
(1.142)\end{array}$ & $\begin{array}{l}-2.085^{* *} \\
(1.060)\end{array}$ & $\begin{array}{l}-1.241 \\
(1.806)\end{array}$ & $\begin{array}{l}-2.472^{* * *} \\
(0.557)\end{array}$ & $\begin{array}{l}-2.278^{* * *} \\
(0.517)\end{array}$ & $\begin{array}{l}-2.484^{* * * *} \\
(0.772)\end{array}$ \\
\hline $\begin{array}{l}\text { Number of Counties } \\
\text { Mean of Dependent Variable } \\
\mathrm{R}^{2}\end{array}$ & $\begin{array}{l}150 \\
0.87 \\
0.39\end{array}$ & $\begin{array}{l}150 \\
0.87 \\
0.44\end{array}$ & $\begin{array}{l}150 \\
0.87 \\
0.55\end{array}$ & $\begin{array}{c}145 \\
17.29 \\
0.43\end{array}$ & $\begin{array}{c}145 \\
17.29 \\
0.46\end{array}$ & $\begin{array}{c}145 \\
17.29 \\
0.46\end{array}$ & $\begin{array}{l}150 \\
8.73 \\
0.37\end{array}$ & $\begin{array}{l}150 \\
8.73 \\
0.43\end{array}$ & $\begin{array}{l}150 \\
8.73 \\
0.46\end{array}$ \\
\hline $\begin{array}{l}\text { State Fixed Effects } \\
\text { Geo-climatic Controls }\end{array}$ & $\begin{array}{l}\text { Yes } \\
\text { Yes }\end{array}$ & $\begin{array}{l}\text { Yes } \\
\text { Yes }\end{array}$ & $\begin{array}{l}\text { Yes } \\
\text { Yes }\end{array}$ & $\begin{array}{l}\text { Yes } \\
\text { Yes }\end{array}$ & $\begin{array}{l}\text { Yes } \\
\text { Yes }\end{array}$ & $\begin{array}{l}\text { Yes } \\
\text { Yes }\end{array}$ & $\begin{array}{l}\text { Yes } \\
\text { Yes }\end{array}$ & $\begin{array}{l}\text { Yes } \\
\text { Yes }\end{array}$ & $\begin{array}{l}\text { Yes } \\
\text { Yes }\end{array}$ \\
\hline $\begin{array}{l}\text { Land Productivity Measures: } \\
\text { Baseline Measures } \\
\text { Additional Measures } \\
\text { Cubic Polynomials }\end{array}$ & $\begin{array}{l}\text { Yes } \\
\text { No } \\
\text { No }\end{array}$ & $\begin{array}{l}\text { Yes } \\
\text { Yes } \\
\text { No }\end{array}$ & $\begin{array}{l}\text { Yes } \\
\text { Yes } \\
\text { Yes }\end{array}$ & $\begin{array}{l}\text { Yes } \\
\text { No } \\
\text { No }\end{array}$ & $\begin{array}{l}\text { Yes } \\
\text { Yes } \\
\text { No }\end{array}$ & $\begin{array}{l}\text { Yes } \\
\text { Yes } \\
\text { Yes }\end{array}$ & $\begin{array}{l}\text { Yes } \\
\text { No } \\
\text { No }\end{array}$ & $\begin{array}{l}\text { Yes } \\
\text { Yes } \\
\text { No }\end{array}$ & $\begin{array}{l}\text { Yes } \\
\text { Yes } \\
\text { Yes }\end{array}$ \\
\hline
\end{tabular}

Notes: Robust standard errors reported in parentheses. ${ }^{* *}$ Significant at the $1 \%$ level; ${ }^{* *}$ Significant at the $5 \%$ level; ${ }^{*}$ Significant at the $10 \%$ level. 
Table A5: Excluding Provincial Capitals and Urban Counties

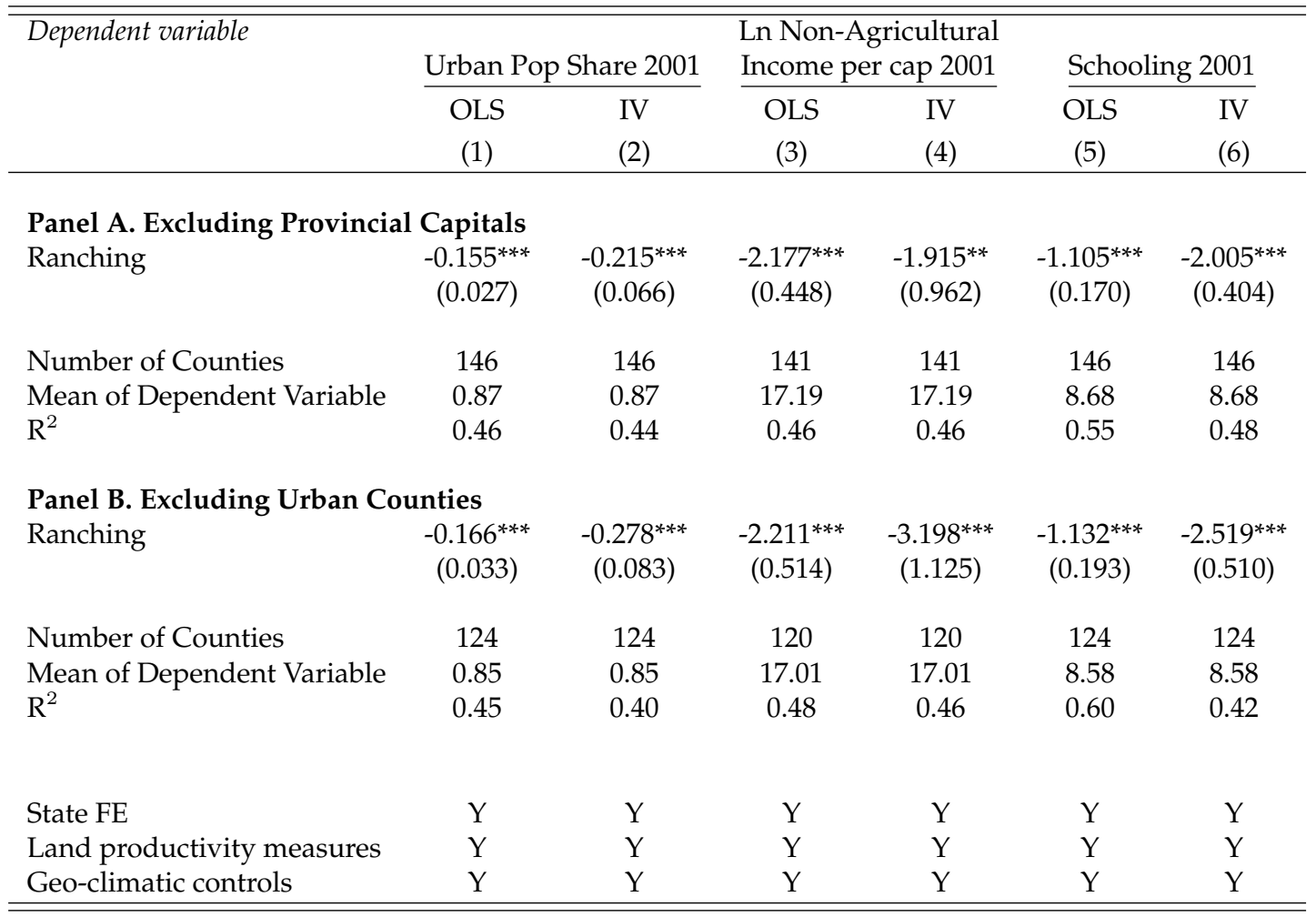

Notes: Robust standard errors reported in parentheses. ${ }^{* * *}$ Significant at the $1 \%$ level; ${ }^{* *}$ Significant at the $5 \%$ level; * Significant at the $10 \%$ level. 
Table A6: Conley Standard Errors

\begin{tabular}{|c|c|c|c|c|c|c|}
\hline \multirow[t]{3}{*}{ Dependent variable } & \multicolumn{6}{|c|}{ Ln Non-Agricultural } \\
\hline & OLS & IV & OLS & IV & OLS & IV \\
\hline & $(1)$ & $(2)$ & (3) & $(4)$ & $(5)$ & (6) \\
\hline Ranching & -0.161 & -0.255 & -2.623 & -2.701 & -1.364 & -2.472 \\
\hline Huber-White robust standard errors & $(0.027)^{* * *}$ & $(0.074)^{* * *}$ & $(0.514)^{* * *}$ & $(1.142)^{* *}$ & $(0.247)^{* * *}$ & $(0.557)^{* * *}$ \\
\hline Conley standard errors with cutoff $50 \mathrm{~km}$ & $(0.027)^{* * *}$ & $(0.079)^{* * *}$ & $(0.478)^{* * *}$ & $(1.193)^{* *}$ & $(0.261)^{* * *}$ & $(0.637)^{* * *}$ \\
\hline Conley standard errors with cutoff $100 \mathrm{~km}$ & $(0.028)^{* * *}$ & $(0.066)^{* * *}$ & $(0.441)^{* * *}$ & $(1.094)^{* *}$ & $(0.266)^{* * * *}$ & $(0.560)^{* * * *}$ \\
\hline Conley standard errors with cutoff $150 \mathrm{~km}$ & $(0.027)^{* * *}$ & $(0.064)^{* * *}$ & $(0.496)^{* * *}$ & $(1.080)^{* *}$ & $(0.279)^{* * *}$ & $(0.603)^{* * *}$ \\
\hline Conley standard errors with cutoff $200 \mathrm{~km}$ & $(0.027)^{* * *}$ & $(0.065)^{* * *}$ & $(0.601)^{* * *}$ & $(1.010)^{* * *}$ & $(0.293)^{* * *}$ & $(0.531)^{* * *}$ \\
\hline Conley standard errors with cutoff $250 \mathrm{~km}$ & $(0.018)^{* * *}$ & $(0.032)^{* * *}$ & $(0.551)^{* * *}$ & $(0.798)^{* * *}$ & $(0.249)^{* * *}$ & $(0.310)^{* * *}$ \\
\hline State FE & $\mathrm{Y}$ & $\mathrm{Y}$ & $\mathrm{Y}$ & $\mathrm{Y}$ & $\mathrm{Y}$ & $\mathrm{Y}$ \\
\hline Land productivity measures & $\mathrm{Y}$ & $\mathrm{Y}$ & $\mathrm{Y}$ & $\mathrm{Y}$ & $\mathrm{Y}$ & $\mathrm{Y}$ \\
\hline Geo-climatic controls & $\mathrm{Y}$ & $\mathrm{Y}$ & $\mathrm{Y}$ & $\mathrm{Y}$ & $\mathrm{Y}$ & $\mathrm{Y}$ \\
\hline
\end{tabular}

Notes: Robust standard errors reported in parentheses. ${ }^{* *}$ Significant at the $1 \%$ level; ${ }^{* *}$ Significant at the $5 \%$ level; * Significant at the $10 \%$ level. 
Table A7: Effects of Agricultural Productivity on Industrialization

\begin{tabular}{|c|c|c|c|c|c|c|}
\hline & \multicolumn{2}{|c|}{$\begin{array}{c}\text { Share of Population } \\
\text { in Manufacturing } 1947\end{array}$} & \multicolumn{2}{|c|}{$\begin{array}{c}\text { Share of Population } \\
\text { in Manufacturing } 1970\end{array}$} & \multicolumn{2}{|c|}{$\begin{array}{l}\text { Share of Labor Force } \\
\text { in Manufacturing } 2001\end{array}$} \\
\hline & $(1)$ & $(2)$ & $(3)$ & $(4)$ & (5) & $(6)$ \\
\hline Mean of Crop-Specific Productivities & $\begin{array}{c}-0.542 \\
(1.013)\end{array}$ & $\begin{array}{c}-0.393 \\
(1.080)\end{array}$ & $\begin{array}{c}0.464 \\
(0.846)\end{array}$ & $\begin{array}{c}0.502 \\
(0.892)\end{array}$ & $\begin{array}{l}-1.018 \\
(1.784)\end{array}$ & $\begin{array}{l}-1.139 \\
(1.763)\end{array}$ \\
\hline First Principal Component of Crop_Specific Productivities & $\begin{array}{c}0.049 \\
(0.096)\end{array}$ & $\begin{array}{c}0.035 \\
(0.102)\end{array}$ & $\begin{array}{l}-0.048 \\
(0.080)\end{array}$ & $\begin{array}{l}-0.052 \\
(0.085)\end{array}$ & $\begin{array}{c}0.094 \\
(0.169)\end{array}$ & $\begin{array}{c}0.106 \\
(0.167)\end{array}$ \\
\hline Average Growth in Mean of Crop-Specific Productivities & & $\begin{array}{c}0.021 \\
(0.025)\end{array}$ & & $\begin{array}{c}0.006 \\
(0.022)\end{array}$ & & $\begin{array}{l}-0.018 \\
(0.054)\end{array}$ \\
\hline Ranching & $\begin{array}{l}-0.023^{* *} \\
(0.012)\end{array}$ & $\begin{array}{l}-0.022^{*} \\
(0.012)\end{array}$ & $\begin{array}{c}-0.037^{* * *} \\
(0.010)\end{array}$ & $\begin{array}{c}-0.037^{* * * *} \\
(0.011)\end{array}$ & $\begin{array}{c}-0.080^{* * *} \\
(0.019)\end{array}$ & $\begin{array}{c}-0.081^{* * * *} \\
(0.019)\end{array}$ \\
\hline Number of Counties & 147 & 147 & 150 & 150 & 150 & 150 \\
\hline Mean of Dependent Variable & 0.03 & 0.03 & 0.05 & 0.05 & 0.17 & 0.17 \\
\hline $\mathrm{R}^{2}$ & 0.16 & 0.16 & 0.49 & 0.49 & 0.46 & 0.46 \\
\hline State Fixed Effects & Yes & Yes & Yes & Yes & Yes & Yes \\
\hline Geo-climatic Controls & Yes & Yes & Yes & Yes & Yes & Yes \\
\hline
\end{tabular}

Notes: OLS estimates. Robust standard errors reported in parentheses. ${ }^{* *}$ Significant at the $1 \%$ level; ${ }^{* *}$ Significant at the $5 \%$ level; ${ }^{*}$ Significant at the $10 \%$ level. 
Table A8: Effects of Agricultural Prices on Industrialization

\begin{tabular}{|c|c|c|c|c|c|c|c|c|c|}
\hline & \multicolumn{3}{|c|}{$\begin{array}{c}\text { Share of Population } \\
\text { in Manufacturing } 1947 \\
\end{array}$} & \multicolumn{3}{|c|}{$\begin{array}{c}\text { Share of Population } \\
\text { in Manufacturing } 1970 \\
\end{array}$} & \multicolumn{3}{|c|}{$\begin{array}{l}\text { Share of Labor Force } \\
\text { in Manufacturing } 2001\end{array}$} \\
\hline & $(1)$ & $(2)$ & $(3)$ & $(4)$ & $(5)$ & $(6)$ & $(7)$ & $(8)$ & $(9)$ \\
\hline Ranching & $\begin{array}{c}-0.023^{* *} \\
(0.012)\end{array}$ & $\begin{array}{l}-0.065^{*} \\
(0.039)\end{array}$ & $\begin{array}{l}-0.079 * * \\
(0.031)\end{array}$ & $\begin{array}{c}-0.037^{* * *} \\
(0.010)\end{array}$ & $\begin{array}{l}-0.054^{*} \\
(0.028)\end{array}$ & $\begin{array}{c}-0.052^{* * *} \\
(0.017)\end{array}$ & $\begin{array}{c}-0.080^{* * *} \\
(0.019)\end{array}$ & $\begin{array}{l}-0.129^{* * *} \\
(0.032)\end{array}$ & $\begin{array}{l}-0.085 \\
(0.092)\end{array}$ \\
\hline Average Agricultural Prices 1914-1947 & & $\begin{array}{c}-0.050 \\
(0.050)\end{array}$ & & & & & & & \\
\hline Coefficient of Variation of Agricultural Prices 1914-1947 & & & $\begin{array}{c}-0.112 \\
(0.069)\end{array}$ & & & & & & \\
\hline Average Agricultural Prices 1914-1970 & & & & & $\begin{array}{c}-0.009 \\
(0.017)\end{array}$ & & & & \\
\hline Coefficient of Variation of Agricultural Prices 1914-1970 & & & & & & $\begin{array}{c}-0.086 \\
(0.104)\end{array}$ & & & \\
\hline Average Agricultural Prices 1914-2001 & & & & & & & & $\begin{array}{l}-0.030 \\
(0.018)\end{array}$ & \\
\hline Coefficient of Variation of Agricultural Prices 1914-2001 & & & & & & & & & $\begin{array}{r}0.019 \\
(0.292)\end{array}$ \\
\hline Number of Counties & 147 & 147 & 147 & 150 & 150 & 150 & 150 & 150 & 150 \\
\hline Mean of Dependent Variable & 0.03 & 0.03 & 0.03 & 0.05 & 0.05 & 0.05 & 0.17 & 0.17 & 0.17 \\
\hline $\mathrm{R}^{2}$ & 0.16 & 0.17 & 0.18 & 0.49 & 0.50 & 0.50 & 0.46 & 0.47 & 0.46 \\
\hline State Fixed Effects & Yes & Yes & Yes & Yes & Yes & Yes & Yes & Yes & Yes \\
\hline Geo-climatic Controls & Yes & Yes & Yes & Yes & Yes & Yes & Yes & Yes & Yes \\
\hline
\end{tabular}

Notes: Robust standard errors reported in parentheses. ${ }^{* * *}$ Significant at the $1 \%$ level; ** Significant at the $5 \%$ level; ${ }^{*}$ Significant at the $10 \%$ level. 
Table A9: Seasonality

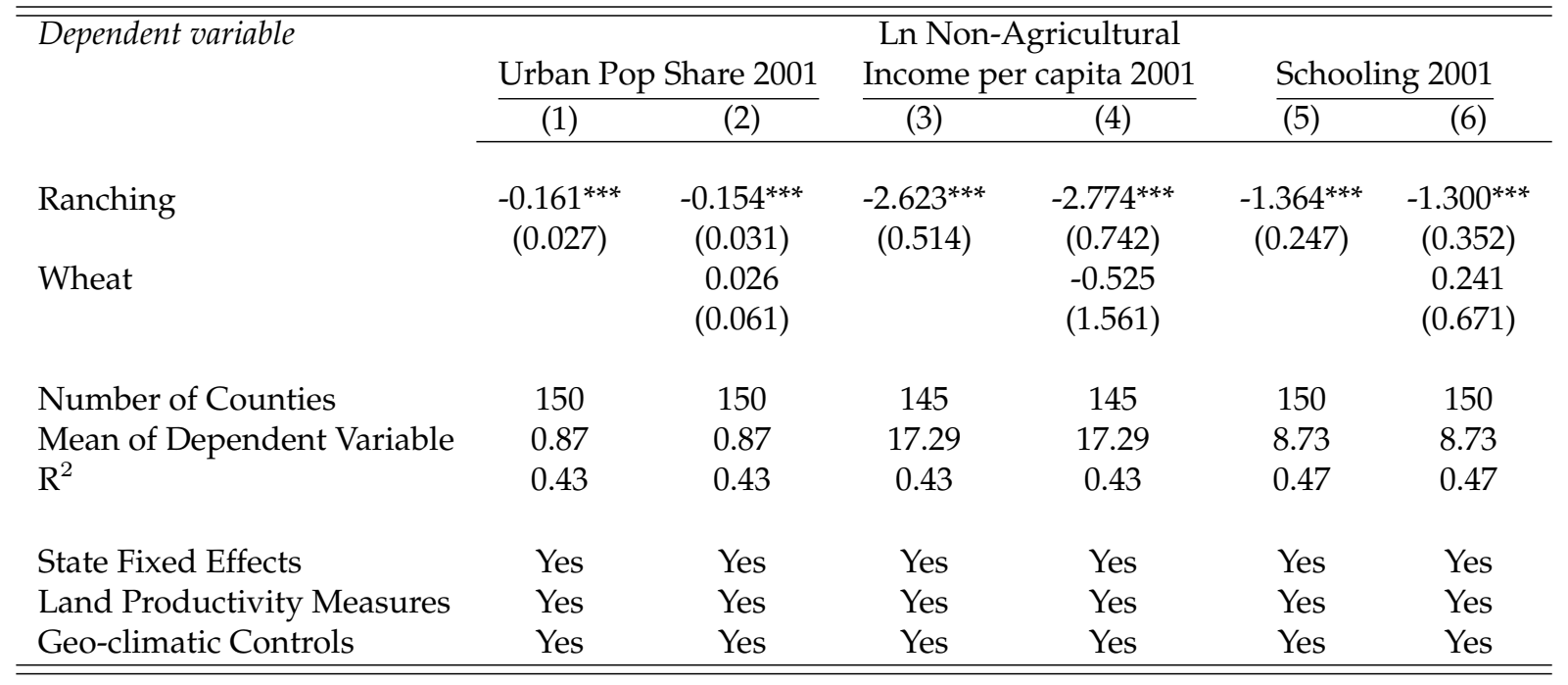

Notes: OLS estimates. Robust standard errors reported in parentheses. ${ }^{* * *}$ Significant at the $1 \%$ level; ${ }^{* *}$ Significant at the $5 \%$ level; * Significant at the $10 \%$ level.

Table A10: Schools

\begin{tabular}{|c|c|c|c|c|c|}
\hline Dependent variable: & $\begin{array}{c}\text { Schools per } \\
\text { child } \\
1914 \\
(1) \\
\end{array}$ & $\begin{array}{c}\text { Public Schools } \\
\text { per child } \\
1914 \\
(2) \\
\end{array}$ & $\begin{array}{c}\text { Religious Schools } \\
\text { per child } \\
1914 \\
\text { (3) } \\
\end{array}$ & $\begin{array}{c}\text { Private Schools } \\
\text { per child } \\
1914 \\
(4) \\
\end{array}$ & $\begin{array}{c}\text { School } \\
\text { Attendance } \\
1914 \\
(5) \\
\end{array}$ \\
\hline \multicolumn{6}{|l|}{ Panel A. OLS Estimates } \\
\hline Ranching & $\begin{array}{c}0.003^{* * *} \\
(0.001)\end{array}$ & $\begin{array}{c}0.004^{* * *} \\
(0.001)\end{array}$ & $\begin{array}{c}-0.000 \\
(0.000)\end{array}$ & $\begin{array}{c}-0.001^{* * *} \\
(0.000)\end{array}$ & $\begin{array}{c}0.045 \\
(0.056)\end{array}$ \\
\hline Number of Counties & 150 & 150 & 150 & 150 & 150 \\
\hline Mean of Dependent Variable & 0.01 & 0.01 & 0.00 & 0.00 & 0.49 \\
\hline $\mathrm{R}^{2}$ & 0.35 & 0.43 & 0.17 & 0.24 & 0.38 \\
\hline \multicolumn{6}{|l|}{ Panel B. IV Estimates } \\
\hline Ranching & $\begin{array}{c}0.005^{* * *} \\
(0.002)\end{array}$ & $\begin{array}{c}0.007^{* * *} \\
(0.002)\end{array}$ & $\begin{array}{c}-0.000 \\
(0.000)\end{array}$ & $\begin{array}{c}-0.002^{* * *} \\
(0.000)\end{array}$ & $\begin{array}{c}0.139 \\
(0.109)\end{array}$ \\
\hline Number of Counties & 150 & 150 & 150 & 150 & 150 \\
\hline Mean of Dependent Variable & 0.01 & 0.01 & 0.00 & 0.00 & 0.49 \\
\hline $\mathrm{R}^{2}$ & 0.32 & 0.37 & 0.17 & 0.15 & 0.37 \\
\hline State Fixed Effects & Yes & Yes & Yes & Yes & Yes \\
\hline Land Productivity Measures & Yes & Yes & Yes & Yes & Yes \\
\hline Geo-climatic Controls & Yes & Yes & Yes & Yes & Yes \\
\hline
\end{tabular}

Notes: Robust standard errors reported in parentheses. ${ }^{* * *}$ Significant at the $1 \%$ level; ${ }^{* *}$ Significant at the $5 \%$ level; * Significant at the $10 \%$ level. Public schools are those with funding from either the national or provinical government. Religious schools also include those funded by charity. We normalize the number of schools in each category by the number of children in school age (i.e., between 6 and 14 years old). 


\section{Variable Definitions and Sources}

\section{Outcome variables}

Farm capital Intensity 1914. Value of tools, implements, and equipment per hectare. It excludes the value of land and animals. Source: 1914 Census

Railroad Density, 1914. Railroad km / $100 \mathrm{~km} 2$. We construct this measure using a digitized version of the 1914 railroad network map from Randle (1981).

Land concentration, 1914. Share of county-level farmland corresponding to the top $10 \%$ largest farms. Source: 1914 Census

Population Density, 1914, 1947, 1991, 2001. Population / area.

Urban Population Share, 1914, 2001. Population living in cities / total population. The census defines a city as a settlement with more than 2,000 individuals. Source: 1914 Census

European-Born Population Share, 1914. European-born population / total population. Data source: 1914 Census.

Italian Share of Europeans, 1914. Italian-born population / European-born population. Data source: 1914 Census.

Share of Population in Manufacturing 1947, 1970. Manufacturing workers / total population. For 1970, based on microdata drawn from the IPUMS-International 2\% sample (Minnesota Population Center, 2020). Data sources: 1947 Census and IPUMS-International microdata from the 1970 Census.

Share of Population in Labor Force 2001. Manufacturing workers / labor force. Data source: 2001 Census.

Manufacturing Valued Added per Worker 1947. Valued added in manufacturing production / manufacturing workers. Data source: 1947 Census.

Non-agricultural Income per-capita, 1994. The Argentine Statistical Office (Instituto Nacional de Estadística y Censos, INDEC) does not compute GDP at the county level, but we can use measures available from the 1994 National Economic Census (NEC) ("Censo Nacional Económico"). In that year, the Census office surveyed all businesses in the main sectors of the economy (Oil and Natural Gas, Mining, Manufacturing Industries, Electricity, Gas and Water, Retail and Wholesale, Financial Intermediation, Communication, Enterprise Service Providers, and Personal Service Providers), gathering information on production, employment, revenue, costs, and investment. We use the county-level measures of output in all these sectors as a proxy for non-agricultural income, dividing by population in 1991 (the closest year with available data 
at the county leve) expanded by the rate of national population growth between 1991 and the Census year. For the province of Buenos Aires and Santa Fe, there is county-level GDP data available from provincial statistical offices. The correlation betweeen our county-level proxies for non-agricultural income per capita and the official county level income per capita figures is about 95\%.

Income per-capita, 1994. The National Economic Census (NEC) does not include agricultural output in its estimations. We combine the NEC data on output with proxies for crop production value and value of ranching products. Our proxy for crop production value relies on data from the Ministry of Agriculture. For each province, we consider the major agricultural products in 1994 and compute the value of agricultural output as the sum of each crop times its price (from FAOstat). Our proxy for the value of ranching products relies the 2002 Agricultural Census and market prices from the Liniers market, the country's main cattle market, located in the city of Buenos Aires (http:/ / www.mercadodeliniers.com.ar/indexnuevo.htm). We consider cattle categories that are likely to end up in slaughterhouses within a year, inlcuding novillitos, novillos, terneras, terneros and vaquillonas, and use average monthly prices from 1995 (prior data is not available). We compute the estimated value of ranching output as the sum of each cattle category times its price, and the adjust by the ratio between the total number of slaughtered bovines in the years corresponding to the Agricultural Census and the NEC, from which the other data comes from. Finally, we add up our measure for non-agricultural income from the NEC and the proxies for crop production value and value of ranching products, and divide by population in 1991 (the closest year with available data at the county leve) expanded by the rate of national population growth between 1991 and the NEC year.

Skill intensity in Manufacturing, 1947. We rely on the distinction between empleados and (obreros) in the Census. These categories are akin to non-production workers and production workers, and we interpret them as proxies for skilled and unskilled workers. Our measure of skill intensity is the ratio between the number of empleados and total workers in manufacturing. Data source: 1947 Census.

Schools per child, 1914. Number of schools / number of school-age children (between 6 and 14 years old). Data source: 1914 Census

Public schools per child, 1914. Number of public schools / number of school-age children (between 6 and 14 years old). Public schools are schools funded by the National, Provincial, or Municipal government. Data source: 1914 Census

Religious schools per child, 1914. Number religious of public schools / number of school-age children (between 6 and 14 years old). We combine schools financed by charity together with those financed by religious entitites. Data source: 1914 Census 
Private schools per child, 1914. Number private of public schools / number of school-age children (between 6 and 16 years old). Private schools are schools financed by private entities or individuals. Data source: 1914 Census

School Attendance, 1914. Enrollment rate among school-age children (6-14 years old). Data source: 1914 Census.

Years of Schooling, 2001. Average years of schooling for population aged 25 and above. Data source: 2001 Census.

Primary School Completion, 2001. Share of adults between 25 and 60 years of age that have completed primary school. Data source: 2001 Census.

\section{Ranching Specialization}

Ranching, 1914. Share of total county-level agricultural land allocated to ranching activities. Data source: 1914 Census.

Ranching Potential Share. Predicted share of total county-level agricultural land allocated to ranching activities obtained from the FML model, using the same crop-specific attainable yields underlying our land productivity measures, described below.

\section{Land productivity measures and other geo-climatic controls}

Land productivity measures. Maximum and average of normalized attainable yields for pasture grasses, maize, wheat, and flax. These measures were constructed by the FAO's Global AgroEcological Zones project v3.0 (IIASA/FAO, 2012) using climatic data, including precipitation, temperature, wind speed, sunshine hours and relative humidity (based on which they determine thermal and moisture regimes), together with crop-specific measures of cycle length (i.e. days from sowing to harvest), thermal suitability, water requirements, and growth and development parameters (harvest index, maximum leaf area index, maximum rate of photosynthesis, etc). Combining these data, the GAEZ model determines the maximum attainable yield (measured in tons per hectare per year) for each crop in each grid cell of $0.083 \times 0.083$ degrees. We use FAO's measures of agro-climatic yields (based solely on climate, not on soil conditions). In all cases we consider yields under rain-fed conditions for intermediate levels of inputs/technology. Index of land suitability for cultivation. As an additional land productivity measure, one of our robustness checks uses a suitability index constructed by Ramankutty et al. (2002), to be interpreted as the probability that a given area is cultivated.

Temperature. County-level mean annual temperature measured in Celsius degrees. Data source: IIASA/FAO (2012). 
Rainfall. County-level average annual precipitation measured in mm. Data source: IIASA/FAO (2012).

Elevation. County-level average terrain elevation in km. Data source: IIASA/FAO (2012).

Terrain ruggedness. County-level average of terrain ruggedness by Nunn and Puga (2012), drawn from https://diegopuga.org/data/rugged/.

Distance to Buenos Aires. Straight line distance from the centroid of each county to Buenos Aires City, in km, calculated with GIS software.

\section{Predicted price index for agricutural output, averages and coefficients of variation}

We use data on export prices for beef, corn, and wheat between 1914 and 2001 from Ferreres et al. (2005). For each county, we consider the shares of ranching, corn, and wheat in local land use in 1914. We normalize all export prices to 1 in that year. For each year, we calculate a predicted price index for each county's agricultural output by multiplying product shares by the correspoding prices. Lacking data for other crops, we rescale the shares of the three products with available data by their added total, so that the rescaled shares add up to one for each county; this is equivalent to assuming that the price corresponding to the share for all other products evolves just like the combined share of the three products with price data. With the yearly predicted price index values, we calculate the average for 1914-1947, 1914-1970, and 1914-2001, and (to capture volatility) the coefficient of variation for the same three periods. 